\title{
Geothermal potential and origin of natural thermal fluids in the northern Lake Abaya area, Main Ethiopian Rift, East Africa
}

\author{
A. Minissale a,*, G. Corti a , F. Tassi a, ${ }^{\text {a, }}$, T.H. Darrah ${ }^{\text {c }}$, O. Vaselli a,b ${ }^{\text {a, D. Montanari }}{ }^{\mathrm{a}}$, G. Montegrossi ${ }^{\mathrm{a}}$, G. Yirgu ${ }^{\mathrm{d}}$, \\ E. Selmo ${ }^{\mathrm{e}}, \mathrm{A} \cdot \mathrm{Teclu}^{\mathrm{f}}$ \\ a CNR-Italian Council for Research, IGG-Institute of Geosciences and Earth Resources, Via La Pira 4, 50121 Firenze, Italy \\ b Department of Earth Sciences, University of Florence, Via La Pira 4, 50121 Firenze, Italy \\ c School of Earth Sciences, Ohio State University, 275 Mendenhall Laboratory, 125 South Oval Mall, Columbus, OH 43210-1398, USA \\ d School of Earth Sciences, Faculty of Science, Addis Ababa University, P.O. Box 1176, Addis Ababa, Ethiopia \\ e Department of Physics and Earth Sciences, Parco Area delle Scienze, 7/A-43124 Parma, Italy \\ f Geological Survey of Ethiopia, Hydrogeol. Engin. Geol. and Geothermal Dept., P.O. Box 40069, Addis Ababa, Ethiopia
}

\section{A R T I C L E I N F O}

\section{Article history:}

Received 27 September 2016

Received in revised form 13 January 2017

Accepted 14 January 2017

Available online 20 January 2017

\section{Keywords:}

Lake Abaya

Ethiopian Rift

Geothermal potential

Fluid chemistry

\begin{abstract}
A B S T R A C T
In this study, the occurrence, chemical composition, origin and geothermal significance of thermal springs and fumaroles naturally discharging in the area located north of the Lake Abaya (western margin of the Main Ethiopian Rift, East Africa) are reviewed in relation with recent tectonics. All thermal springs showed a dominantly $\mathrm{Na}-\mathrm{HCO}_{3}$ composition, consistent with observations dating from at least 1972, and most of them displayed a narrow range of $\delta \mathrm{D}$ and $\delta^{18} \mathrm{O}$ isotopic compositions for water similar to regional meteoric origins. These observations suggest that water-rock interaction processes occur in all aquifers and dominate the contributions of water that actively circulate within thermal fluids, and also suggest a similar elevation of groundwater recharge throughout the study area. Most of the thermal springs are dominated by a $\mathrm{CO}_{2}$-rich gas phase and discharge along the active faults bordering the western edge of the Main Ethiopian Rift valley. The $\delta^{13} \mathrm{C}$ values of $\mathrm{CO}_{2}$ and the ${ }^{3} \mathrm{He} /{ }^{4} \mathrm{He}$ isotopic ratios are consistent with the presence of mantle-derived fluids similar to what is observed in many other areas along the kinematically active African Rift, especially within Ethiopia. The application of geothermometric techniques in the liquid and the gas phases suggests the presence of a deep reservoir in which the fluids equilibrated at a maximum temperature of approximately $180^{\circ} \mathrm{C}$. Additionally, the presence of fumaroles at boiling temperatures and water/mud boiling pools in several places suggests that the geothermal reservoir is positioned at a relatively shallow depth and likely located in the western side of the study area. The analysis of data collected throughout time reveals that the waters of Lake Abaya have experienced an increase in salinity of $20 \%$ paralleled contemporaneously with a decrease in $\mathrm{pH}$ and $\delta^{18} \mathrm{O}$ and $\delta \mathrm{D}$ of water in the last 40 years; these changes do not appear to be related to climate changeinduced increases in temperature or evaporation at the global scale.
\end{abstract}

(c) 2017 Elsevier B.V. All rights reserved.

\section{Introduction}

Along the majority of the East African Rift System (EARS), there is strong geothermal potential for power generation (Teklemarian, 2008). Nonetheless, the power-generation potential for the majority of these geothermal resources has not been completely assessed to date. One of the main reasons, consistent with incomplete geothermal evaluations in many other areas in the World, is because hot deep hydrothermal fluids only occasionally come in contact with shallow cold aquifer(s) along ascending convective branches in fault systems. The importance of this factor has been recognized for decades and is clearly demonstrated by common mixing processes occurring at various

\footnotetext{
* Corresponding author.

E-mail address: minissa@igg.cnr.it (A. Minissale).
}

degrees between hot rising fluids and cold meteoric descending fluids (Fournier, 1977; Arnòrsson, 1985).

The contrasting circulation pathways and processes for uprising hot, typically mantle-derived (convection and buoyancy-driven along faults) and descending cold, typically meteorically-derived (groundwaterdriven) groundwater, limit the potential for these fluids to interact in most settings (e.g. Minissale, 2004). As an example of the lack of communication between these different processes and pathways, most active worldwide volcanoes rarely show significant amounts of hot fluid discharge at the surface, while most active hydrothermal systems may have the intrinsic capability to seal the top and lateral margins of their main reservoir(s) along cooler temperature boundaries, by precipitating silica, silicates, and other minerals, preventing further meteoric water interaction (Facca and Tonani, 1967). For these reasons, there are significant limitations for reliably estimating the equilibrium temperatures of 
geothermal waters by chemical geothermometers (e.g. Minissale, 2002). Still, as interest in evaluating the geothermal potential of EARS increases, and there is a growing demand for better methods to determine the geothermal characteristics of thermal springs.

In Ethiopia, many volcanoes have shown recent or ongoing activity (Biggs et al., 2011) and are characterized by hydrothermal systems with significant geothermal potential (Fig. 1). One example is the Aluto-Langano geothermal system in the central part of the Main Ethiopian Rift (MER), where InSar (Interferometric Synthetic Aperture Radar) analysis has identified ongoing surface deformation with cycles of uplift and subsidence (Biggs et al., 2011), and which hosts a welldeveloped hydrothermal reservoir and a productive geothermal field (Gizaw, 1993; Teklemarian et al., 1996; Samrock et al., 2015). Besides Aluto, knowledge of the geothermal potential of other areas in Ethiopia has increased in recent years; examples include i) Tendaho in the Afar depression (Didana et al., 2015), ii) Gedemsa-Sodere and iii) Corbetti (Teklemarian and Kebede, 2010; Kebede, 2014); these latter two are located within the MER. Apart from these areas, there are several other promising places along the MER that are still in a preliminary exploration phase (Purschel et al., 2013).

In this work, we focused on the southernmost of these poorly explored areas, which is located north of Lake Abaya (Fig. 1). Similar to other places along the EARS, the area shows significant recent and ongoing volcano-tectonic activity (Chernet, 2011; Corti et al., 2013; Philippon et al., 2014) and thermal emissions at the surface as springs and fumaroles (U.N.D.P., 1973; Craig et al., 1977; Chernet, 2011). The aim of the present study was to review the chemical and isotopic data of the thermal springs available in the literature, coupled with new data from field-work conducted in February 2015, during which freegas discharges and fumaroles, not previously analysed, were collected. Secondary goals include locating the source of the thermal anomaly responsible for the geothermal manifestations and evaluating the

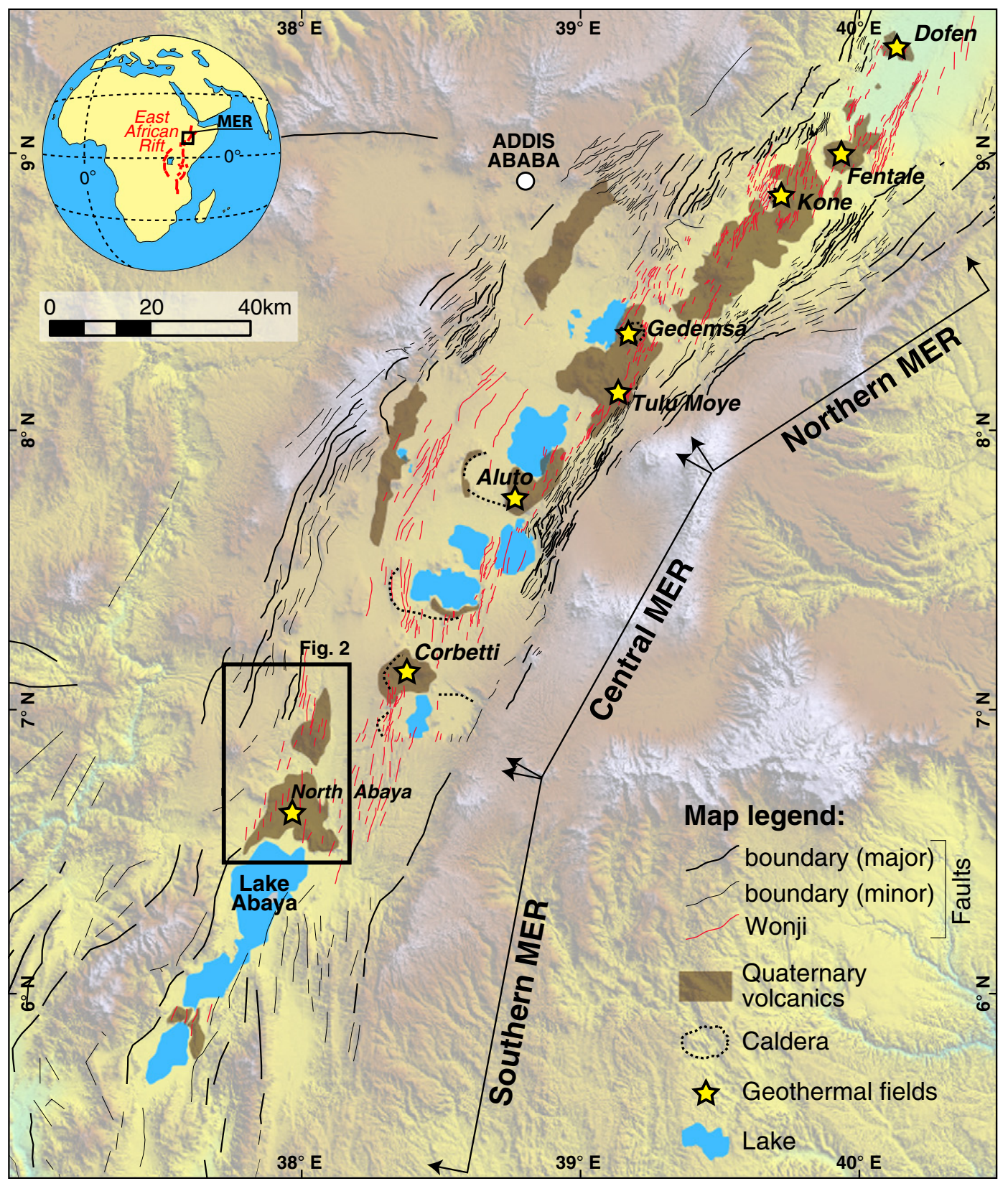

Fig. 1. Tectonic setting of the Main Ethiopian Rift (MER). 
potential for a relationship between the location of surface manifestations with respect to active tectonics or volcanoes.

\section{Background}

\subsection{Geological setting}

The study area is located on the western margin of the MER, north of Lake Abaya in central Ethiopia, along the transition zone between the central and southern sector of the MER (Fig. 1). The area is characterized by an absence of a major rift escarpment. Instead, the topographic transition between the rift floor and the plateau is gentle and accommodated by numerous roughly NNE-SSW-trending normal faults (Fig. 2). The plan-view architecture of these faults is characterized by an array of sigmoidal, right-stepping en-echelon normal or oblique faults, indicative of oblique extension with respect to the roughly NE-SW-trending rift. Radiocarbon dating of faulted material pointed to significant Late Pleistocene-Holocene (post-30 ka) activity on these normal faults (Corti et al., 2013).

Lithologically, the area consists of volcanic and volcano-sedimentary formations, mostly associated with the main rifting events (Fig. 2). The oldest volcanic products are represented by 30-36 My old (Oligocene), pre-rift basalts of the Trap Series (Zanettin et al., 1978; Mohr and Zanettin, 1988), overlain by Pliocene peralkaline pantelleritic Nazret ignimbrites and trachytic lava flows (Chewkare Ignimbrites of Chernet, 2011). These units are in turn overlain by sequences made of alluvial and rare lacustrine sediments, with interbedded pyroclastics and basalt flows of Pleistocene-Holocene age (De la Torre et al., 2007).

The volcanic activity is typically marked by bimodal activities. The first is constituted by rhyolitic centers characterized by the emission of large volumes of peralkaline lava flows, domes and pyroclastic deposits. These volcanic centers are common along the western rift margin at Hobitcha and Doguna volcanoes, although some acidic volcanoes are observed at the rift axis (e.g. Chericha volcano). Very recent obsidian and pitchstone flows are located near the southern edge of the Hobitcha caldera, at Salewa-Dore and Hako volcanic centres (Fig. 2). These latter centers probably represent the youngest rhyolitic activity in the area and are characterized by ongoing steam vents and steaming ground activity (Chernet, 2011).

The second stage of activity is characterized by basaltic lava flows, scoria cones and phreatomagmatic deposits. The basalts are associated with the recent faults located in the western part of the rift valley, as documented by NNE-SSW alignments of numerous scoria cones (Fig. 2) marking the main fault swarms (Corti et al., 2013). The youngest episodes of basaltic eruptions are associated with the intense faulting that characterizes the margin in correspondence to the Hobitcha caldera. In total, the volume of felsic lava extruded during the Quaternary is over $200 \mathrm{~km}^{3}$ (Chernet, 2011), out of which about $100 \mathrm{~km}^{3}$ are from the Doguna volcano, comparable to contemporaneous basaltic lava erupted from the many cones shown in Fig. 2. Besides Salewa-Dore, fumaroles also characterize some peripheral basaltic centers of the Doguna volcano near Bilbo (Fig. 2).

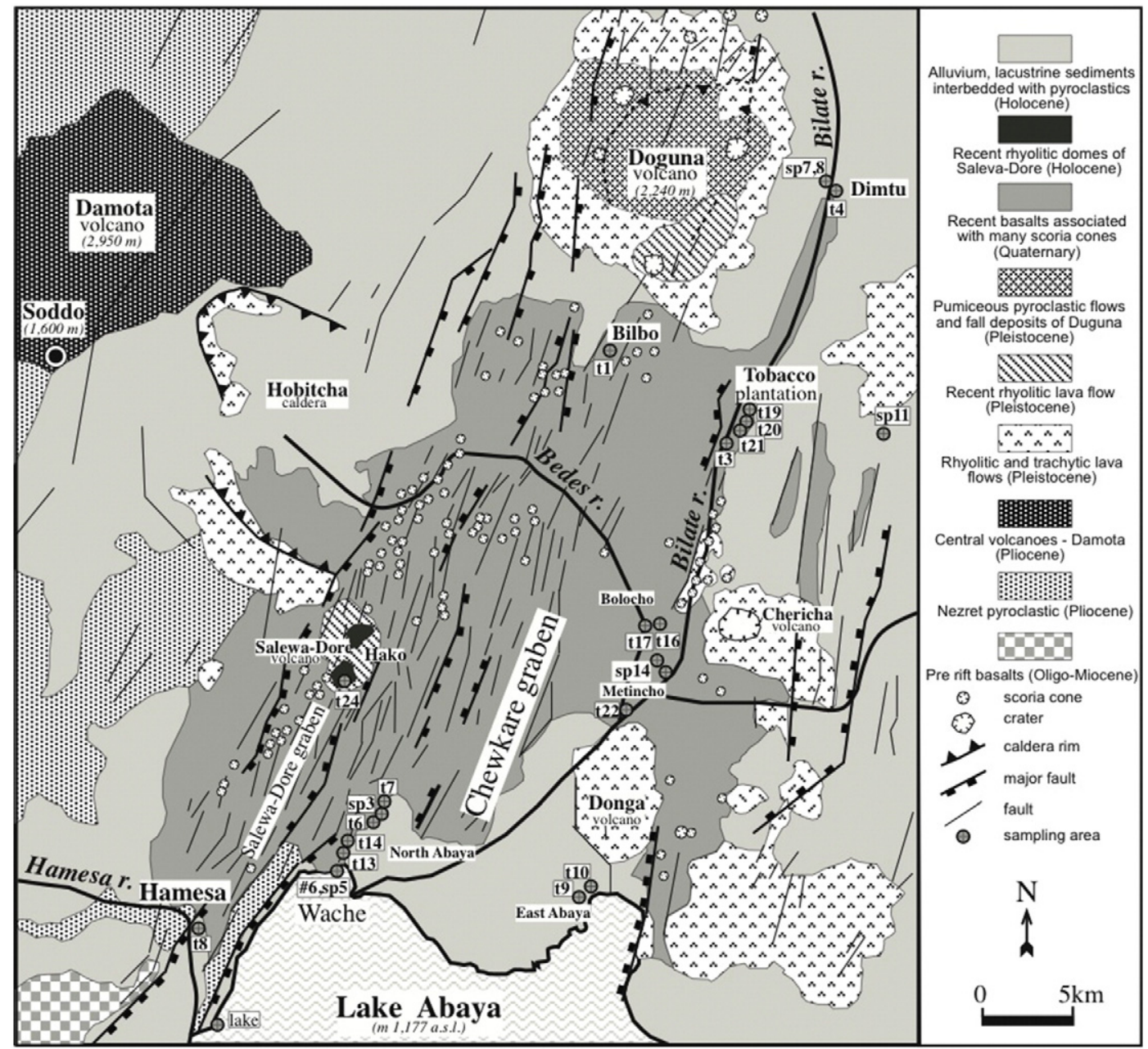

Fig. 2. Geological and structural map of the north Lake Abaya area. 
Table 1

\begin{tabular}{|c|c|c|c|c|c|c|c|c|c|c|c|c|c|c|c|}
\hline Code & Sample name & Year & Type & Latitude & Longitude & $\frac{\text { Elev. }}{\mathrm{m}}$ & $\frac{\text { Flow }}{\mathrm{L} / \mathrm{s}}$ & $\frac{\mathrm{T}}{{ }^{\circ} \mathrm{C}}$ & $\mathrm{pH}$ & $\frac{\mathrm{TDS}}{\mathrm{ppm}}$ & $\frac{\mathrm{Ca}}{\mathrm{ppm}}$ & $\frac{\mathrm{Mg}}{\mathrm{ppm}}$ & $\frac{\mathrm{Na}}{\mathrm{ppm}}$ & $\frac{\mathrm{K}}{\mathrm{ppm}}$ & $\frac{\mathrm{HCO}_{3}}{\mathrm{ppm}}$ \\
\hline \#6 & Abaya 6 & 1972 & gay & $6^{\circ} 37^{\prime}$ ? ?" N & $37^{\circ} 54^{\prime} ? ?^{\prime \prime} \mathrm{E}$ & & 12 & 95.0 & 9.60 & 4016 & 0.2 & 0.10 & 1290 & 240 & 1065 \\
\hline et-72 & Abaya 6 & 1977 & gay & & & & & 95.0 & 9.58 & 4803 & 0.2 & 0.10 & 1320 & 222 & 1979 \\
\hline eth-12 & Abaya 6 & 1990 & gay & $6^{\circ} 37^{\prime}$ ? ?" N & $37^{\circ} 54^{\prime} ? ?^{\prime \prime} \mathrm{E}$ & & & 96.0 & & & & & & & \\
\hline sp-5 & Sp-5 (Wache) & 2000 & gay & $6^{\circ} 36^{\prime} 37^{\prime \prime} \mathrm{N}$ & $37^{\circ} 54^{\prime} 01^{\prime \prime} \mathrm{E}$ & & & 95.0 & 9.50 & 4719 & 0.2 & 0.10 & 1327 & 174 & 1667 \\
\hline \#7 & Abaya 7 & 1972 & bub.p & & & & & 93.0 & & & & & & & \\
\hline et-73 & Abaya 7 & 1977 & bub.p & & & & & 90.8 & 6.60 & & & & & & \\
\hline eth-13 & Abaya 7 & 1990 & bub.p & & & & & 88.0 & & & & & & & \\
\hline$t-13$ & $\mathrm{~N}$ of Abaia field 7 & 2015 & bub.p & $6^{\circ} 36^{\prime} 54^{\prime \prime} \mathrm{N}$ & $37^{\circ} 54^{\prime} 04^{\prime \prime} \mathrm{E}$ & 1207 & & 91.5 & & & & & & & \\
\hline$t-14$ & $\mathrm{~N}$ of Abaia field 9 & 2015 & bub.p & $6^{\circ} 36^{\prime} 56^{\prime \prime} \mathrm{N}$ & $37^{\circ} 54^{\prime} 04^{\prime \prime} \mathrm{E}$ & 1207 & & 94.0 & 7.60 & & 7.5 & $<0.1$ & 14 & 5 & \\
\hline \#8 & Abaya 8 & 1972 & spg & & & & 12 & 65.5 & 7.20 & 1983 & 20.0 & 14.00 & 500 & 50 & 1286 \\
\hline et-74 & Abaya 8 & 1977 & sgg & & & & & 67.0 & 6.95 & 2296 & 21.0 & 8.00 & 600 & 50 & 1476 \\
\hline sp-6 & Sp-6 (Wache) & 2000 & spg & $6^{\circ} 37^{\prime} 01^{\prime \prime} \mathrm{N}$ & $37^{\circ} 54^{\prime} 06^{\prime \prime} \mathrm{E}$ & & & 68.0 & 6.80 & 2039 & 12.0 & 9.00 & 510 & 32 & 1431 \\
\hline$\# 10$ & Abaya 10 & 1972 & sgp & & & & 13 & 53.0 & & & & & & & \\
\hline et-75 & Abaya 10 & 1977 & spg & & & & & 50.0 & 6.76 & 2226 & 30.0 & 16.00 & 505 & 54 & 1474 \\
\hline$t-15$ & Boramitta & 2015 & sgp & $6^{\circ} 37^{\prime} 12^{\prime \prime} \mathrm{N}$ & $37^{\circ} 54^{\prime} 08^{\prime \prime} \mathrm{E}$ & 1195 & & 56.4 & 6.59 & 2132 & 24.3 & 8.59 & 581 & 38 & 1403 \\
\hline \#15 & Chewkare 15 & 1972 & $\mathrm{sp}$ & & & & 20 & 60.0 & & 2027 & 18.0 & 9.00 & 530 & 50 & 1318 \\
\hline et-76 & Chewkare 15 & 1977 & $\mathrm{sp}$ & & & & & 66.5 & 6.80 & 1968 & 8.0 & 5.00 & 518 & 48 & 1302 \\
\hline sp-4 & Sp-4 (Boramita) & 2000 & $\mathrm{sp}$ & $6^{\circ} 38^{\prime} 14^{\prime \prime} \mathrm{N}$ & $37^{\circ} 54^{\prime} 27^{\prime \prime} \mathrm{E}$ & & & 66.0 & 6.40 & 2043 & 16.0 & 5.50 & 530 & 41 & 1382 \\
\hline$t-6$ & North of Abaya & 2015 & bp & $6^{\circ} 38^{\prime} 11^{\prime \prime} \mathrm{N}$ & $37^{\circ} 54^{\prime} 35^{\prime \prime} \mathrm{E}$ & 1200 & 15 & 62.6 & 6.60 & 2115 & 27.0 & 7.74 & 586 & 34 & 1382 \\
\hline \#16 & Chewkare 16 & 1972 & $\mathrm{sp}$ & & & & 9 & 42.0 & 7.20 & 1308 & 52.0 & 48.00 & 230 & 39 & 815 \\
\hline et-77 & Chewkare 16 & 1977 & $\mathrm{sp}$ & & & & & 42.0 & 7.22 & 1322 & 45.0 & 48.00 & 238 & 28 & 832 \\
\hline sp-3 & Sp-3 (Boramita) & 2000 & $\mathrm{sp}$ & $6^{\circ} 38^{\prime} 14^{\prime \prime} \mathrm{N}$ & $37^{\circ} 54^{\prime} 51^{\prime \prime} \mathrm{E}$ & & & 41.0 & 6.90 & 1260 & 53.0 & 56.00 & 213 & 26 & 887 \\
\hline \#17 & Chewkare 17 & 1972 & $\mathrm{sp}$ & & & & & 37.0 & 6.40 & 378 & 24.0 & 9.00 & 56 & 14 & 275 \\
\hline \#20 & Bilate village & 1972 & $\mathrm{sp}$ & & & & 85 & 39.5 & & & & & & & \\
\hline \#18 & Chewkare 18 & 1972 & $\mathrm{sp}$ & & & & 33 & 42.0 & & & & & & & \\
\hline $\mathrm{sp}-2$ & Sp-2 (Chewokare) & 2000 & $\mathrm{sp}$ & $6^{\circ} 38^{\prime} 37^{\prime \prime} \mathrm{E}$ & $37^{\circ} 55^{\prime} 16^{\prime \prime} \mathrm{E}$ & & & 42.0 & 7.60 & 1185 & 3.0 & 40.00 & 230 & 26 & 800 \\
\hline$t-7$ & $\mathrm{~N}$ of Abaya spring & 2015 & $\mathrm{sp}$ & $6^{\circ} 38^{\prime} 46^{\prime \prime} \mathrm{N}$ & $37^{\circ} 55^{\prime} 09^{\prime \prime} \mathrm{E}$ & 1197 & 1 & 40.6 & 7.22 & 1212 & 6.5 & 48.71 & 239 & 31 & 762 \\
\hline \#19 & Bilate & 1972 & $\mathrm{sp}$ & & & & 2 & 68.0 & 7.40 & 1007 & 8.0 & 7.00 & 280 & 22 & 580 \\
\hline sp-9 & Sp-9 (Bilate) & 2000 & $\mathrm{sp}$ & $6^{\circ} 48^{\prime} 14^{\prime \prime} \mathrm{N}$ & $38^{\circ} 05^{\prime} 16^{\prime \prime} \mathrm{E}$ & & & 67.0 & 7.90 & 1098 & 6.5 & 1.80 & 286 & 16 & 634 \\
\hline$t-3$ & Tobacco plantation 1 & 2015 & bp & $6^{\circ} 48^{\prime} 39^{\prime \prime} \mathrm{N}$ & $38^{\circ} 05^{\prime} 13^{\prime \prime} \mathrm{E}$ & 1346 & & 63.4 & 7.28 & 1114 & 7.7 & 2.02 & 326 & 19 & 695 \\
\hline sp-10 & Sp-10 (Bilate) & 2000 & $\mathrm{sp}$ & $6^{\circ} 48^{\prime} 14^{\prime \prime} \mathrm{N}$ & $38^{\circ} 05^{\prime} 16^{\prime \prime} \mathrm{E}$ & & & 73.0 & 7.80 & 974 & 6.8 & 1.90 & 302 & 16 & 589 \\
\hline sp-11 & Sp-11 (Bilate) & 2000 & $\mathrm{sp}$ & $6^{\circ} 48^{\prime} 38^{\prime \prime} \mathrm{N}$ & $38^{\circ} 09^{\prime} 40^{\prime \prime} \mathrm{E}$ & & & 61.0 & 7.50 & 1031 & 6.4 & 1.50 & 280 & 13 & 677 \\
\hline sp-12 & Sp-12 (Bilate) & 2000 & $\mathrm{sp}$ & $6^{\circ} 48^{\prime} 38^{\prime \prime} \mathrm{N}$ & $38^{\circ} 05^{\prime} 40^{\prime \prime} \mathrm{E}$ & & & 59.0 & 7.40 & 918 & 15.6 & 2.40 & 238 & 19 & 595 \\
\hline$t-19$ & Tobacco plantation 2 & 2015 & $\mathrm{sp}$ & $6^{\circ} 49^{\prime} 05^{\prime \prime} \mathrm{N}$ & $38^{\circ} 05^{\prime} 39^{\prime \prime} \mathrm{E}$ & 1355 & & 51.1 & 7.22 & 811 & 17.0 & 2.98 & 218 & 19 & 512 \\
\hline$t-20$ & Tobacco plantation 4 & 2015 & $\mathrm{sp}$ & $6^{\circ} 49^{\prime} 01^{\prime \prime} \mathrm{N}$ & $38^{\circ} 05^{\prime} 39^{\prime \prime} \mathrm{E}$ & 1355 & & 51.5 & 7.17 & 808 & 14.4 & 2.95 & 219 & 19 & 510 \\
\hline$t-21$ & Tobacco plantation 5 & 2015 & $\mathrm{sp}$ & $6^{\circ} 48^{\prime} 52^{\prime \prime} \mathrm{N}$ & $38^{\circ} 05^{\prime} 31^{\prime \prime} \mathrm{E}$ & 1348 & & 58.0 & 7.28 & 932 & 11.3 & 2.61 & 260 & 18 & 589 \\
\hline et-78 & Bilate-Tobacco & 1977 & $\mathrm{sp}$ & $6^{\circ} 47^{\prime}$ ? ?" N & $38^{\circ} 05^{\prime}$ ? ?" E & & & 51.0 & 7.60 & 1057 & 10.0 & 2.00 & 283 & 15 & 695 \\
\hline sp-13 & Sp-13 (Methincho) & 2000 & $\mathrm{sp}$ & $6^{\circ} 40^{\prime} 24^{\prime \prime} \mathrm{N}$ & $38^{\circ} 02^{\prime} 10^{\prime \prime} \mathrm{E}$ & & & 52.0 & 8.20 & 1258 & 5.2 & 3.30 & 342 & 18 & 827 \\
\hline$t-22$ & Metincho (Bolocho) & 2015 & $\mathrm{sp}$ & $6^{\circ} 40^{\prime} 30^{\prime \prime} \mathrm{N}$ & $38^{\circ} 02^{\prime} 07^{\prime \prime} \mathrm{E}$ & 1219 & & 50.3 & 7.81 & 1402 & 6.1 & 4.02 & 403 & 26 & 872 \\
\hline \#24 & Bolocho (Wogeri) & 1972 & $\mathrm{sp}$ & & & & 75 & 74.0 & 8.40 & 972 & 2.0 & 1.00 & 312 & 9 & 542 \\
\hline
\end{tabular}


Table 1 (continued)

\begin{tabular}{|c|c|c|c|c|c|c|c|c|c|c|c|c|c|c|c|c|c|}
\hline Code & Sample name & $\frac{\mathrm{CO}_{3}}{\mathrm{ppm}}$ & $\frac{\mathrm{SO}_{4}}{\mathrm{ppm}}$ & $\frac{\mathrm{Cl}}{\mathrm{ppm}}$ & $\frac{\mathrm{SiO}_{2}}{\mathrm{ppm}}$ & $\frac{\mathrm{NH}_{4}}{\mathrm{ppm}}$ & $\frac{\mathrm{Li}}{\mathrm{ppm}}$ & $\frac{\mathrm{F}}{\mathrm{ppm}}$ & $\frac{\mathrm{Br}}{\mathrm{ppm}}$ & $\frac{\mathrm{HBO}_{2}}{\mathrm{ppm}}$ & $\frac{{ }^{2} \mathrm{H} / \mathrm{H}}{\% \text { smow }}$ & $\frac{{ }^{18} \mathrm{O} /{ }^{16} \mathrm{O}}{\% \text { osmow }}$ & $\frac{{ }^{3} \mathrm{H}}{\mathrm{uT}}$ & $\frac{{ }^{13} \mathrm{CO}_{2}(\mathrm{DIC})}{\% \text { V-PBD }}$ & $\frac{{ }^{13} \mathrm{CO}_{2}(\mathrm{~g})}{\% \mathrm{~V}-\mathrm{PBD}}$ & $\mathrm{R} / \mathrm{Ra}$ & Reference \\
\hline \#6 & Abaya 6 & 606 & 104.0 & 711 & 204 & 1.00 & 1.80 & 43.00 & & 15.10 & & & & & & & UNDP (1973) \\
\hline et-72 & Abaya 6 & 400 & 152.0 & 730 & 134 & & & 31.50 & 0.20 & 10.30 & -5.7 & -0.66 & & -4.2 & -5.1 & 4.0 & Craig et al. (1977) \\
\hline eth-12 & Abaya 6 & & & & & & & & & & & & & & & & Darling (1990) \\
\hline sp-5 & Sp-5 (Wache) & 728 & 89.0 & 734 & 433 & & & 44.00 & & 11.69 & -5.4 & -0.47 & 0.2 & & & & Teclu (2003) \\
\hline \#7 & Abaya 7 & & & & & & & & & & & & & & & & UNDP (1973) \\
\hline et-73 & Abaya 7 & & & 4 & & & & & & & 13.3 & 6.06 & & & & 4.3 & Craig et al. (1977) \\
\hline eth-13 & Abaya 7 & & & & & & & & & & & & & & & & Darling (1990) \\
\hline$t-13$ & $\mathrm{~N}$ of Abaia field 7 & & & & & & & & & & & & & & -3.8 & 4.5 & This paper \\
\hline$t-14$ & $\mathrm{~N}$ of Abaia field 9 & & & 7 & & 18.60 & & 0.09 & 0.04 & & & & & & -4.3 & 5.0 & This paper \\
\hline \#8 & Abaya 8 & 53 & 12.0 & 48 & 146 & 0.19 & 0.58 & 13.00 & & 2.80 & & & & & & & UNDP (1973) \\
\hline et-74 & Abaya 8 & & 25.0 & 116 & 131 & & & 9.00 & 0.08 & & -8.7 & -2.88 & & & & & Craig et al. (1977) \\
\hline sp-6 & Sp-6 (Wache) & & 13.0 & 52 & 171 & & & 14.00 & & 0.41 & -8.8 & -2.93 & 0.7 & & & & Teclu (2003) \\
\hline \#10 & Abaya 10 & & & & & & & & & & & & & & & & UNDP (1973) \\
\hline et-75 & Abaya 10 & & 89.0 & 58 & 127 & & & 13.70 & & 2.20 & -7.8 & -2.48 & & -0.7 & -5.1 & 5.6 & Craig et al. (1977) \\
\hline $\mathrm{t}-15$ & Boramitta & & 19.4 & 57 & 110 & 0.09 & 0.07 & 15.66 & 0.35 & 0.20 & -10.0 & -2.92 & & & -5.4 & 7.5 & This paper \\
\hline \#15 & Chewkare 15 & 42 & 12.0 & 48 & 141 & 0.32 & 0.62 & 14.00 & & 3.20 & & & & & & & UNDP (1973) \\
\hline et-76 & Chewkare 15 & & 21.0 & 66 & 122 & & & 13.70 & 0.35 & & -9.4 & -2.98 & & 1.7 & -4.9 & 7.2 & Craig et al. (1977) \\
\hline sp-4 & Sp-4 (Boramita) & & 13.0 & 72 & 156 & & & 15.00 & & 0.90 & -9.3 & -2.93 & 0.4 & & & & Teclu (2003) \\
\hline$t-6$ & North of Abaya & & 20.0 & 58 & 153 & 0.13 & 0.08 & 19.00 & 0.24 & 0.26 & -11.1 & -2.97 & & & -6.0 & & This paper \\
\hline \#16 & Chewkare 16 & 25 & 18.0 & 81 & 116 & & 0.65 & 2.00 & & 1.60 & & & & & & & UNDP (1973) \\
\hline et-77 & Chewkare 16 & & 29.0 & 102 & 107 & & & 2.85 & & & -7.1 & -2.90 & & -1.2 & & 7.3 & Craig et al. (1977) \\
\hline sp-3 & Sp-3 (Boramita) & & 24.0 & 103 & 123 & & & 2.80 & & 0.81 & -7.4 & -2.51 & 0.7 & & & & Teclu (2003) \\
\hline \#17 & Chewkare 17 & & $<10$ & $<10$ & 122 & & $<0.05$ & $<2$ & 0.30 & 4.40 & & & & & & & UNDP (1973) \\
\hline \#20 & Bilate village & & & & & & & & & & & & & & & & UNDP (1973) \\
\hline \#18 & Chewkare 18 & & & & & & & & & & & & & & & & UNDP (1973) \\
\hline sp-2 & Sp-2 (Chewokare) & & 22.0 & 104 & 110 & & & 2.60 & & 0.12 & -6.9 & -2.81 & 0.0 & & & & Teclu (2003) \\
\hline$t-7$ & $\mathrm{~N}$ of Abaya spring & & 22.6 & 102 & 105 & 0.07 & 0.01 & 2.77 & 0.31 & 0.20 & -9.6 & -3.00 & & & & & This paper \\
\hline \#19 & Bilate & 54 & 11.0 & 45 & 126 & & 0.07 & 18.00 & & 1.10 & & & & & & & UNDP (1973) \\
\hline sp-9 & Sp-9 (Bilate) & & 11.0 & 151 & 150 & & & 19.00 & & 1.02 & -3.2 & -1.91 & 0.5 & & & & Teclu (2003) \\
\hline$t-3$ & Tobacco plantation 1 & & 15.7 & 49 & 92 & 0.10 & 0.03 & 18.11 & 0.17 & 0.27 & -4.8 & -1.97 & & & & & This paper \\
\hline sp-10 & Sp-10 (Bilate) & & 12.0 & 55 & 130 & & & 20.00 & & 0.12 & -3.3 & -1.89 & 0.7 & & & & Teclu (2003) \\
\hline sp-11 & Sp-11 (Bilate) & & 10.0 & 50 & 128 & & & 20.00 & & 0.12 & -3.5 & -1.92 & 0.3 & & & & Teclu (2003) \\
\hline sp-12 & Sp-12 (Bilate) & & 9.0 & 56 & 118 & & & 15.00 & & 0.49 & -5.1 & -2.05 & 0.8 & & & & Teclu (2003) \\
\hline$t-19$ & Tobacco plantation 2 & & 11.0 & 31 & 105 & 0.05 & 0.02 & 9.80 & 0.24 & 0.17 & -8.3 & -2.45 & & & & & This paper \\
\hline$t-20$ & Tobacco plantation 4 & & 11.6 & 31 & 143 & 0.05 & 0.02 & 9.54 & 0.26 & 0.16 & -8.0 & -2.45 & & & & & This paper \\
\hline$t-21$ & Tobacco plantation 5 & & 13.3 & 38 & 101 & 0.05 & 0.03 & 13.19 & 0.23 & 0.18 & -6.7 & -2.36 & & & & & This paper \\
\hline et-78 & Bilate-Tobacco & & 21.0 & 31 & 136 & & & 5.80 & 1.00 & & -5.7 & -2.17 & & -5.0 & & 8.3 & Craig et al. (1977) \\
\hline sp-13 & Sp-13 (Methincho) & & 30.0 & 40 & 144 & & & 16.00 & & 1.63 & -8.3 & -2.67 & 0.3 & & & & Teclu (2003) \\
\hline$t-22$ & Metincho (Bolocho) & & 35.1 & 56 & 119 & 0.10 & 0.03 & 14.67 & 0.27 & 0.23 & -10.6 & -2.91 & & & & & This paper \\
\hline \#24 & Bolocho (Wogeri) & 47 & 33.0 & 26 & 78 & & 0.15 & 40.00 & 0.80 & 0.80 & & & & & & & UNDP (1973) \\
\hline
\end{tabular}


Table 1 (continued)

\begin{tabular}{|c|c|c|c|c|c|c|c|c|c|c|c|c|c|c|c|}
\hline Code & Sample name & Year & Type & Latitude & Longitude & $\frac{\text { Elev. }}{\mathrm{m}}$ & $\frac{\text { Flow }}{\mathrm{L} / \mathrm{s}}$ & $\frac{\mathrm{T}}{{ }^{\circ} \mathrm{C}}$ & $\mathrm{pH}$ & $\frac{\mathrm{TDS}}{\mathrm{ppm}}$ & $\frac{\mathrm{Ca}}{\mathrm{ppm}}$ & $\frac{\mathrm{Mg}}{\mathrm{ppm}}$ & $\frac{\mathrm{Na}}{\mathrm{ppm}}$ & $\frac{\mathrm{K}}{\mathrm{ppm}}$ & $\frac{\mathrm{HCO}_{3}}{\mathrm{ppm}}$ \\
\hline sp14 & Sp-14 (Bolocho) & 2000 & sp & $6^{\circ} 42^{\prime} 14^{\prime \prime} \mathrm{N}$ & $38^{\circ} 02^{\prime} 42^{\prime \prime} \mathrm{E}$ & & & 89.0 & 7.80 & 4357 & 1.1 & 0.10 & 1270 & 66 & 2830 \\
\hline$t-16$ & Bolocho & 2015 & bub.p & $6^{\circ} 43^{\prime} 18^{\prime \prime} \mathrm{N}$ & $38^{\circ} 02^{\prime} 47^{\prime \prime} \mathrm{E}$ & 1255 & & 65.8 & 7.30 & 3665 & 6.6 & 1.42 & 1364 & 80 & 2019 \\
\hline $\mathrm{t}-17$ & Bolocho 2 & 2015 & boil.p. & $6^{\circ} 43^{\prime} 22^{\prime \prime} \mathrm{N}$ & $38^{\circ} 02^{\prime} 42^{\prime \prime} \mathrm{E}$ & 1240 & & 91.5 & 7.70 & 4541 & 3.5 & 1.30 & 1345 & 76 & 2917 \\
\hline \#17 & Humasa hot spring & 1972 & sp & & & & 11 & 37.0 & 6.40 & 394 & 24.0 & 9.00 & 56 & 14 & 275 \\
\hline et-82 & Humasa hot spring & 1977 & sp & & & & & 35.0 & 6.90 & 375 & 22.0 & 9.00 & 58 & 14 & 244 \\
\hline sp-1 & Sp-1 (Humasa) & 2000 & sp & $6^{\circ} 34^{\prime} 19^{\prime \prime} \mathrm{N}$ & $37^{\circ} 49^{\prime} 19^{\prime \prime} \mathrm{E}$ & & & 35.0 & 6.70 & 341 & 20.0 & 7.00 & 54 & 9 & 239 \\
\hline$t-8$ & Humasa spring & 2015 & sp & $6^{\circ} 34^{\prime} 02^{\prime \prime} \mathrm{N}$ & $37^{\circ} 49^{\prime} 29^{\prime \prime} \mathrm{E}$ & 1235 & & 36.2 & 6.36 & 366 & 24.7 & 9.20 & 58 & 12 & 256 \\
\hline don & Donga East Abaya & 1972 & $\mathrm{sp}$ & & & & & $48-51$ & 7.50 & & & & & & \\
\hline t-9 & East Abaya 1 (Donga) & 2015 & sp & $6^{\circ} 35^{\prime} 25^{\prime \prime} \mathrm{N}$ & $38^{\circ} 00^{\prime} 57^{\prime \prime} \mathrm{E}$ & 1188 & & 47.9 & 7.87 & 1570 & 4.8 & 2.33 & 441 & 52 & 958 \\
\hline$t-10$ & East Abaya 2 (Donga) & 2015 & sp & $6^{\circ} 35^{\prime} 24^{\prime \prime} \mathrm{N}$ & $38^{\circ} 00^{\prime} 59^{\prime \prime} \mathrm{E}$ & 1187 & & 45.5 & 7.79 & 1531 & 14.0 & 2.30 & 430 & 43 & 922 \\
\hline \#22 & Bilbo & 1972 & fum & & & & 1 & 95.0 & 7.60 & 113 & 2.0 & 1.00 & 9 & 6 & 82 \\
\hline \#23 & Bilbo (Bodicho) & 1972 & sp & & & & & 92.5 & 8.30 & 1093 & 4.0 & 0.24 & 310 & 23 & 643 \\
\hline $\mathrm{t}-1$ & Bilbo & 2015 & fum & $6^{\circ} 50^{\prime} 45^{\prime \prime} \mathrm{N}$ & $38^{\circ} 02^{\prime} 01^{\prime \prime} \mathrm{E}$ & 1392 & & 95.2 & 8.17 & 3 & 1.3 & & 2 & & \\
\hline \#20 & Dimtu springs & 1972 & sp & & & & 83 & 39.5 & 7.00 & 784 & 16.0 & 5.00 & 194 & 27 & 495 \\
\hline sp-7 & Bilbo & 2000 & sp & $6^{\circ} 56^{\prime} 05^{\prime \prime} \mathrm{N}$ & $38^{\circ} 07^{\prime} 42^{\prime \prime} \mathrm{E}$ & & & 40.0 & 7.10 & 816 & 12.8 & 3.00 & 192 & 16 & 514 \\
\hline sp-8 & Dimtu springs & 2000 & sp & $6^{\circ} 56^{\prime} 05^{\prime \prime} \mathrm{N}$ & $38^{\circ} 07^{\prime} 42^{\prime \prime} \mathrm{E}$ & & & 39.0 & 7.40 & 818 & 12.0 & 2.80 & 202 & 16 & 540 \\
\hline$t-4$ & Dimtu well & 2015 & w & $6^{\circ} 55^{\prime} 41^{\prime \prime} \mathrm{N}$ & $38^{\circ} 08^{\prime} 04^{\prime \prime} \mathrm{E}$ & 1480 & 30 & 53.8 & 8.00 & 896 & 4.9 & 0.28 & 268 & 21 & 549 \\
\hline hak & Salwa-Hako domes & 1972 & fum & & & & & 90.0 & & & & & & & \\
\hline hak2 & Salwa-Hako domes & 1972 & sp & & & & & 42.5 & & & & & & & \\
\hline $\mathrm{t}-24$ & Hako & 2015 & steam & & & 1593 & & 39.6 & & & & & & & \\
\hline $\mathrm{t}-12$ & Shinkeko well & 2015 & w & $6^{\circ} 30^{\prime} 40^{\prime \prime} \mathrm{N}$ & $37^{\circ} 46^{\prime} 36^{\prime \prime} \mathrm{E}$ & 1205 & & 28.8 & 7.16 & 721 & 77.4 & 30.52 & 73 & 5 & 515 \\
\hline $\mathrm{t}-18$ & Soddo well & 2015 & w & $6^{\circ} 52^{\prime} 23^{\prime \prime} \mathrm{N}$ & $37^{\circ} 46^{\prime} 17^{\prime \prime} \mathrm{E}$ & 2091 & & 21.1 & 7.01 & 31 & 2.8 & 0.74 & 6 & 5 & 12 \\
\hline$t-23$ & Maze well & 2015 & w & $6^{\circ} 37^{\prime} 35^{\prime \prime} \mathrm{N}$ & $37^{\circ} 52^{\prime} 08^{\prime \prime} \mathrm{E}$ & 1288 & & 27.2 & 7.46 & 305 & 10.8 & 25.61 & 36 & 9 & 213 \\
\hline sp-15 & Gola & 2000 & $\mathrm{sp}$ & $6^{\circ} 52^{\prime} 37^{\prime \prime} \mathrm{N}$ & $37^{\circ} 47^{\prime} 09^{\prime \prime} \mathrm{E}$ & & & 25.0 & 5.60 & 30 & 1.4 & 0.36 & 5 & 3 & 15 \\
\hline LA & Lake Abaya & 1972 & lake & & & 1169 & & 26.0 & & 932 & 18.0 & 5.00 & 226 & 20 & 595 \\
\hline et-84 & Lake Abaya 1 & 1977 & lake & $6^{\circ} 15^{\prime} ?$ ? ?" N & $37^{\circ} 48^{\prime}$ ? ?" E & 1386 & & & 8.85 & 754 & 14.0 & 3.00 & 188 & 21 & 437 \\
\hline LA2 & Lake Abaya 2 & 1977 & lake & & & 1169 & & & 8.70 & 368 & & & & & 368 \\
\hline A.L. & (Abaya lake) & 2000 & lake & $6^{\circ} 31^{\prime} 40^{\prime \prime} \mathrm{N}$ & $37^{\circ} 50^{\prime} 00^{\prime \prime} \mathrm{E}$ & 1169 & & 28.0 & 8.60 & 779 & 16.0 & 4.00 & 206 & 15 & 463 \\
\hline $\mathrm{t}-11$ & Lake Abaya & 2015 & lake & $6^{\circ} 30^{\prime} 18^{\prime \prime} \mathrm{N}$ & $37^{\circ} 46^{\prime} 50^{\prime \prime} \mathrm{E}$ & 1185 & & 29.4 & 8.53 & 849 & 17.1 & 3.20 & 229 & 15 & 506 \\
\hline $\mathrm{Hr}$ & Humasa river & 1972 & river & & & & & & 8.70 & 462 & 20.0 & 7.00 & 92 & 17 & 293 \\
\hline et-83 & Humasa river & 1977 & river & & & & & & 7.85 & 157 & 13.0 & 3.00 & 13 & 12 & 109 \\
\hline $\mathrm{HR}$ & Humasa river & 2000 & river & $6^{\circ} 34^{\prime} 10^{\prime \prime} \mathrm{N}$ & $37^{\circ} 49^{\prime} 27^{\prime \prime} \mathrm{E}$ & & & 24.0 & 7.90 & 161 & 10.1 & 2.70 & 4 & 7 & 133 \\
\hline et-62 & Bilate river 1 & 1977 & river & & & & & & 8.40 & 846 & 14.0 & 2.00 & 213 & 27 & 548 \\
\hline et-79 & Bilate river 2 & 1977 & river & & & & & & 8.80 & & & & & & \\
\hline Bil.r & Bil.R (Bilate river) & 2000 & river & $6^{\circ} 40^{\prime} 08^{\prime \prime} \mathrm{N}$ & $38^{\circ} 01^{\prime} 53^{\prime \prime} \mathrm{E}$ & & & 24.0 & 7.20 & 194 & 7.9 & 1.60 & 40 & 9 & 122 \\
\hline BR & BR (Bedesa river) & 2000 & river & $6^{\circ} 52^{\prime} 18^{\prime \prime} \mathrm{N}$ & $37^{\circ} 56^{\prime} 13^{\prime \prime} \mathrm{E}$ & & & 23.0 & 8.30 & 128 & 2.0 & 0.96 & 24 & 10 & 85 \\
\hline \multirow[t]{4}{*}{ et- 80} & rain Sodo $2000 \mathrm{~m}$ & 1977 & rain & & & 2000 & & & & & & & & & \\
\hline & Addis Ababa rain ( $\max$ ) & & rain & & & 2350 & & & & & & & & & \\
\hline & Addis Ababa rain (av.) & 1977 & rain & & & 2350 & & & & & & & & & \\
\hline & Addis Ababa rain (min) & & rain & & & 2350 & & & & & & & & & \\
\hline
\end{tabular}


Table 1 (continued)

\begin{tabular}{|c|c|c|c|c|c|c|c|c|c|c|c|c|c|c|c|c|c|}
\hline Code & Sample name & $\frac{\mathrm{CO}_{3}}{\mathrm{ppm}}$ & $\frac{\mathrm{SO}_{4}}{\mathrm{ppm}}$ & $\frac{\mathrm{Cl}}{\mathrm{ppm}}$ & $\frac{\mathrm{SiO}_{2}}{\mathrm{ppm}}$ & $\frac{\mathrm{NH}_{4}}{\mathrm{ppm}}$ & $\frac{\mathrm{Li}}{\mathrm{ppm}}$ & $\frac{\mathrm{F}}{\mathrm{ppm}}$ & $\frac{\mathrm{Br}}{\mathrm{ppm}}$ & $\frac{\mathrm{HBO}_{2}}{\mathrm{ppm}}$ & $\frac{{ }^{2} \mathrm{H} / \mathrm{H}}{\% \text { smow }}$ & $\frac{{ }^{18} \mathrm{O} /{ }^{16} \mathrm{O}}{\% \text { smow }}$ & $\frac{{ }^{3} \mathrm{H}}{\mathrm{uT}}$ & $\frac{{ }^{13} \mathrm{CO}_{2}(\mathrm{DIC})}{\% \text { V-PBD }}$ & $\frac{{ }^{13} \mathrm{CO}_{2}(\mathrm{~g})}{\% \circ \mathrm{V}-\mathrm{PBD}}$ & $\mathrm{R} / \mathrm{Ra}$ & Reference \\
\hline sp14 & Sp-14 (Bolocho) & & 64.0 & 126 & 251 & & & 42.00 & & 4.52 & 0.9 & -0.84 & 0.4 & & & & Ayele et al. (2002) \\
\hline$t-16$ & Bolocho & & 62.0 & 132 & 216 & 0.26 & 0.12 & 42.00 & 0.56 & 0.42 & 2.2 & 0.00 & & & & & This paper \\
\hline$t-17$ & Bolocho 2 & & 73.0 & 125 & 243 & 0.10 & 0.13 & 40.13 & 0.66 & 0.47 & -0.2 & -1.08 & & & -4.9 & & This paper \\
\hline \#17 & Humasa hot spring & & 8.0 & 8 & 122 & & 0.04 & 1.00 & 0.30 & 4.40 & & & & & & & UNDP (1973) \\
\hline et- 82 & Humasa hot spring & & 24.0 & 4 & 103 & & & 1.80 & 0.53 & & -7.3 & -2.48 & & & & & Craig et al. (1977) \\
\hline sp-1 & Sp-1 (Humasa) & & 4.0 & 8 & 144 & & & 1.70 & & 0.68 & -6.6 & -2.37 & 0.6 & & & & Teclu (2003) \\
\hline $\mathrm{t}-8$ & Humasa spring & & 1.6 & 4 & 159 & 0.05 & 0.01 & 1.61 & 0.07 & 0.09 & -10.4 & -2.71 & & & & & This paper \\
\hline don & Donga East Abaya & & & & & & & & & & & & & & & & UNDP (1973) \\
\hline$t-9$ & East Abaya 1 (Donga) & & 42.7 & 69 & 105 & 0.14 & 0.03 & 13.62 & 0.41 & 0.36 & -9.7 & -2.79 & & & & & This paper \\
\hline$t-10$ & East Abaya 2 (Donga) & & 44.4 & 75 & 124 & 0.06 & 0.03 & 11.41 & 0.31 & 0.34 & -10.9 & -2.74 & & & & & This paper \\
\hline \#22 & Bilbo & & 8.0 & 5 & 80 & & 0.03 & 2.00 & & 1.40 & & & & & & & UNDP (1973) \\
\hline \#23 & Bilbo (Bodicho) & 40 & 40.0 & 33 & 155 & & 0.31 & 16.00 & 0.10 & 0.50 & & & & & & & UNDP (1973) \\
\hline$t-1$ & Bilbo & & 2.7 & 2 & & 0.03 & & 1.80 & & & & & & & -5.6 & 7.4 & This paper \\
\hline \#20 & Dimtu springs & 18 & 11.0 & 18 & 112 & & $<0.05$ & 12.00 & 0.40 & 0.50 & & & & & & & UNDP (1973) \\
\hline sp-7 & Bilbo & & 23.0 & 55 & 118 & & & 15.00 & & 0.72 & -12.4 & -3.12 & 1.0 & & & & Teclu (2003) \\
\hline sp-8 & Dimtu springs & & 22.0 & 23 & 134 & & & 15.00 & & 9.60 & -13.1 & -3.32 & 0.8 & & & & Teclu (2003) \\
\hline$t-4$ & Dimtu well & & 18.6 & 35 & 98 & 0.09 & 0.03 & 22.81 & 0.10 & 0.26 & -11.1 & -2.90 & & & & & This paper \\
\hline hak & Salwa-Hako domes & & & & & & & & & & & & & & & & UNDP (1973) \\
\hline hak2 & Salwa-Hako domes & & & & & & & & & & & & & & & & UNDP (1973) \\
\hline$t-24$ & Hako & & & & & & & & & & & & & & & & This paper \\
\hline$t-12$ & Shinkeko well & & 5.0 & 15 & & 0.04 & 0.00 & 0.69 & 0.15 & 0.08 & -6.1 & -2.01 & & & & & This paper \\
\hline $\mathrm{t}-18$ & Soddo well & & 0.8 & 3 & & 0.06 & 0.00 & 0.04 & 0.18 & 0.17 & -3.1 & -2.24 & & & & & This paper \\
\hline$t-23$ & Maze well & & 4.5 & 5 & & 0.05 & 0.01 & 1.22 & 0.05 & 0.07 & -5.4 & -2.27 & & & & & This paper \\
\hline sp-15 & Gola & & 0.4 & 5 & 36 & & & 0.10 & & 0.69 & -4.6 & -2.18 & 3.5 & & & & Teclu (2003) \\
\hline LA & Lake Abaya & & 27.0 & 41 & 73 & & 0.05 & 7.00 & 0.70 & 1.25 & & & & & & & UNDP (1973) \\
\hline et- 84 & Lake Abaya 1 & & 43.0 & 48 & 39 & & & 6.13 & 1.30 & 0.40 & 49.6 & 7.25 & & 0.7 & & & Craig et al. (1977) \\
\hline LA2 & Lake Abaya 2 & & & & & & & & & & & & & 0.3 & & & Craig et al. (1977) \\
\hline A.L. & (Abaya lake) & & 15.0 & 60 & 19 & & & 6.60 & & 0.98 & 44.4 & 6.54 & 2.8 & & & & Teclu (2003) \\
\hline $\mathrm{t}-11$ & Lake Abaya & & 18.9 & 60 & & 0.15 & 0.01 & 7.50 & 0.49 & 0.38 & 40.2 & 5.69 & & & & & This paper \\
\hline $\mathrm{Hr}$ & Humasa river & 24 & 0.2 & 9 & 74 & & 0.05 & 5.00 & & & & & & & & & UNDP (1973) \\
\hline et-83 & Humasa river & & 0.1 & 7 & 39 & & & 0.80 & 0.30 & & 6.2 & -0.07 & & & & & Craig et al. (1977) \\
\hline $\mathrm{HR}$ & Humasa river & & 0.1 & 4 & 24 & & & 0.50 & & 0.77 & -26.4 & -5.07 & 1.7 & & & & Teclu (2003) \\
\hline et-62 & Bilate river 1 & & 9.0 & 33 & 107 & & & 9.25 & 0.93 & & 8.0 & 0.85 & & & & & Craig et al. (1977) \\
\hline et-79 & Bilate river 2 & & & & & & & & & & 2.2 & 0.14 & & & & & Craig et al. (1977) \\
\hline Bil.r & Bil.R (Bilate river) & & 0.4 & 13 & 31 & & & 2.00 & & 0.57 & -6.3 & -2.26 & 7.4 & & & & Teclu (2003) \\
\hline & BR (Bedesa river) & & 0.4 & 6 & 391 & & & 1.40 & & 0.12 & -7.3 & -2.47 & 0.3 & & & & Teclu (2003) \\
\hline \multirow[t]{4}{*}{ et- 80} & rain Sodo 2000 m & & & 80 & & & & 12.50 & & & -19.2 & -4.50 & & & & & Craig et al. (1977) \\
\hline & Addis Ababa rain (max) & & & & & & & & & & 36.0 & 2.80 & & & & & Levin et al. (2009) \\
\hline & Addis Ababa rain (av.) & & & & & & & & & & 4.0 & -1.40 & & & & & Craig et al. (1977) \\
\hline & Addis Ababa rain (min) & & & & & & & & & & -26.0 & -4.60 & & & & & Levin et al. (2009) \\
\hline
\end{tabular}


The most recent deposits in the area correspond to Holocene lacustrine sediments related to fluctuations of Lake Abaya (Ayenew and Egziabher, 2015), and to fluvial sediments deposited by the Bilate and Gidabo Rivers (the latter outside Fig. 2).

\subsection{Volcano-tectonic activity}

Field structural data indicate that the tectonic activity has played a major role in controlling the recent volcanism (Corti et al., 2013). East-dipping normal faults and their associated antithetic faults gave rise to minor grabens, within which the volcanic vents showed the highest density in the Salewa-Dore area (Fig. 2). These data support the observation that the majority of the volcano-tectonic activity is situated in the western rift margin.

Petrologic and geochemical studies on volcanics have suggested that the volcanic activity is related to magmas generated at depths of 50-70 km, and fractionated at shallow crustal levels (Rooney, 2010). Gravity analysis indicated the existence of a large magmatic intrusion at depth of $10 \mathrm{~km}$ beneath the Doguna volcano (Mahatsente et al., 1999), analogously to what was observed beneath the Wonji magmatic segments in the northern MER (Fig. 1; Keranen et al., 2004).

Local geophysical analyses have highlighted the existence of discrete heat sources at depth, connected to shallow magma chambers, as hypothesized beneath the Doguna volcano (Ayele et al., 2002). From these sources, the circulation of geothermal fluids is likely influenced by the NE-SW normal faults that control the structural pattern of the area; secondary NW-SE structures also seem to play a role in the flow of hot fluids (Ayele et al., 2002). In particular, the magneto-telluric investigations performed so far have suggested the possible presence of deep seated heat sources near the base of the Salewa-Dore rhyolitic dome and in the Dimtu area (Desissa and Lema, 2006). For the northern sectors, gravity and magnetic investigations (Ayele et al., 2002) have suggested the location of the main heat source beneath the Doguna volcano.

\subsection{Previous sampling campaigns on the thermal manifestations}

As described in previous papers and reports, the area north of Lake Abaya hosts several thermal springs, boiling pools, and fumaroles at: i) Wache-Chawokare (up to $96{ }^{\circ} \mathrm{C}$ ), ii) Bolocho (up to $92{ }^{\circ} \mathrm{C}$ ) and BilateTobacco Plantation along the Bilate River (up to $71^{\circ} \mathrm{C}$ ), iii) Donga (up to $48{ }^{\circ} \mathrm{C}$ ), iv) Dimtu (up to $54{ }^{\circ} \mathrm{C}$ in shallow wells), v) Hamesa (up to $37^{\circ} \mathrm{C}$ ) and vi) a couple of fumaroles (mostly steaming ground) at Bilbo $\left(95^{\circ} \mathrm{C}\right.$ ) and Hako $\left(40{ }^{\circ} \mathrm{C}\right.$ ), respectively (Fig. 2). Thermal springs and boiling pools are clearly located along active faults within the rift floor, at elevations varying from $1177 \mathrm{~m}$ to $1350 \mathrm{~m}$, whereas the steaming areas are discharging at higher elevations at the Hako volcano and from the southern flank of the Doguna volcano, respectively.

In 1972, the area was visited by a United Nations mission (U.N.D.P., 1973), during which some of the thermal manifestations presented in this work were analysed. A second United Nations mission was carried out in 1976 by a team from the University of San Diego (Craig et al., 1977). In this second campaign a more detailed sampling program was performed, also producing isotopic data on waters $\left(\delta^{18} \mathrm{O}\right.$ and $\delta \mathrm{D}$; $\delta^{13} \mathrm{C}$-dissolved inorganic carbon) and gas isotopic ratios $\left(\delta^{13} \mathrm{C}^{1}-\mathrm{CO}_{2}\right.$ and ${ }^{3} \mathrm{He} /{ }^{4} \mathrm{He}$ ). In 1990 a mission of the British Geological Survey visited the area (Darling, 1990), although only temperature measurements from the hottest springs bounding the northern shore of the Lake Abaya were gathered. A more recent sampling campaign was organized by the Geological Survey of Ethiopia (Ayele et al., 2002; Teclu, 2003) to provide new chemical and isotopic data on the springs already sampled in 1972 and 1976.

Most recently, in 2015 the Institute of Geosciences and Earth Resources of Florence (CNR-Italian Research Council) organized a new sampling campaign. New chemical and isotopic determinations included: the chemical compositions of the gas phases associated with the thermal springs, and noble gas analyses, including helium $\left({ }^{3} \mathrm{He} /{ }^{4} \mathrm{He}\right)$, neon $\left({ }^{20} \mathrm{Ne} /{ }^{22} \mathrm{Ne},{ }^{21} \mathrm{Ne} /{ }^{22} \mathrm{Ne}\right)$, and $\arg$ on $\left({ }^{38} \mathrm{Ar} /{ }^{36} \mathrm{Ar},{ }^{40} \mathrm{Ar} /{ }^{36} \mathrm{Ar}\right)$ isotopes. The whole dataset from these four sampling campaigns is reported in Table 1 for waters and Table 2 for gases, respectively.

\subsection{Description of thermal manifestations}

Most thermal springs discharge within the rift floor, in clear connection with major, NNE-SSW-trending faults. The springs are located: i) at Wache (Lake Abaya shore), ii) along the western edge of the Chawokare graben, and iii) along the Bilate River at Bolocho, Metincho and the Tobacco plantation (Fig. 2). All of them emerge at elevations varying between the $1177 \mathrm{~m}$ (Lake Abaya) and about $1350 \mathrm{~m}$ (Tobacco plantation). East and west of the Lake Abaya lower temperature thermal springs were found at Hamesa $\left(35-37^{\circ} \mathrm{C}\right)$ and south of Donga volcano $\left(45-48{ }^{\circ} \mathrm{C}\right.$ ) at the elevation of 1235 and $1188 \mathrm{~m}$, respectively (Table 1 ).

At higher elevations there are some thermal wells $\left(54^{\circ} \mathrm{C}\right)$ at Dimtu $(1480 \mathrm{~m})$ and steaming areas at Bilbo $\left(95^{\circ} \mathrm{C}\right)$ at $1393 \mathrm{~m}$ and at Hako $\left(40^{\circ} \mathrm{C}\right.$ ) at about $1600 \mathrm{~m}$. In the 1972 UNDP mission in this latter site, located on the SE flank of the Salewa-Dore volcano, the presence of fumarole(s) or steaming ground at $90{ }^{\circ} \mathrm{C}$ was reported, but this presence was not confirmed in the 1977 or more recent sampling missions. Nevertheless, in 2015 a steaming ground at only $40{ }^{\circ} \mathrm{C}$ was found at the southern of the two Hako domes (Fig. 2).

Among the thermal springs present near the NW shore of Lake Abaya, the most spectacular one was emerging at $96{ }^{\circ} \mathrm{C}$, with a flowrate of $12 \mathrm{~L} / \mathrm{s}$ and coded \#6 (hereafter as Abaya \#6) in 1972 (U.N.D.P., 1973), ET-72 in 1976 (Craig et al., 1977), eth-12 in 1990 (Darling, 1990) and sp-5 in 2000 (Ayele et al., 2002). Unfortunately, this spring was submerged by the lake water in the period between 2000 and 2002 (Ayele et al., 2002) and confirmed by Ayenew and Egziabher (2015) and Belete et al. (2016), who reported 3 to $5 \mathrm{~m}$ oscillation of the lake level in the period 1987-2007.

\section{Methods}

\subsection{Sampling and analytical procedures}

The sampling and analytical procedures described in this section are those related to the 2015 campaign. Temperature and $\mathrm{pH}$ were measured in situ; water samples for anions determination were collected in $100 \mathrm{~mL}$ polyethylene bottles after filtering at $0.45 \mu \mathrm{m}$, whereas filtered and acidified samples collected in $50 \mathrm{~mL}$ bottles were used for the analysis of cations (Venturi et al., 2015). Water isotopes were analysed on samples collected in $100 \mathrm{~mL}$ dark glass bottles.

Gas samples from fumaroles were collected using a sampling line consisting of a $1 \mathrm{~m}$ long titanium tube inserted into the fumarolic vent and connected to glass Dewar tubes. Bubbling gases were sampled using an inverted plastic funnel, submerged in the pools, and Tygon ${ }^{\circledR}$ tube connections. Both fumaroles and bubbling gases were collected in pre-evacuated $60-\mathrm{mL}$ glass Thorion ${ }^{\circledR}$-tapped flasks filled with $20 \mathrm{~mL}$ of a $4 \mathrm{~N} \mathrm{NaOH}$ and $0.15 \mathrm{M} \mathrm{Cd}(\mathrm{OH})_{2}$ suspension (Montegrossi et al., 2001; Vaselli et al., 2006). During sampling, water vapour and acidic gas species $\left(\mathrm{CO}_{2}, \mathrm{SO}_{2}, \mathrm{HCl}\right.$ and $\left.\mathrm{HF}\right)$ dissolve in the alkaline solutions, $\mathrm{H}_{2} \mathrm{~S}$ forms insoluble $\mathrm{CdS}$, whereas low-solubility species $\left(\mathrm{N}_{2}, \mathrm{O}_{2}\right.$, $\mathrm{CO}, \mathrm{H}_{2}, \mathrm{He}, \mathrm{Ar}, \mathrm{CH}_{4}$ and hydrocarbons) are stored in the flask headspace and concentrate in proportion to the quantity of solubilised acidic components in the $\mathrm{NaOH}$.

Steam condensates for water isotope analysis, and dry gases for the analysis of $\mathrm{CO}$ and the ${ }^{13} \mathrm{C} /{ }^{12} \mathrm{C}$ ratio of $\mathrm{CO}_{2}$ were sampled using a water-cooled condenser connected to the sampling line adopted for the soda flasks. An additional gas sample was collected in $100 \mathrm{~mL}$ sampling glass flasks filled with $50 \mathrm{~mL}$ of a $4 \mathrm{~N} \mathrm{NaOH}$ solution for the analysis of helium, neon, and argon abundance and isotopic composition.

Major cations (including $\mathrm{Li}^{+}$and $\mathrm{NH}_{4}^{+}$) and anions (including $\mathrm{Br}^{-}$ and $\mathrm{NO}_{3}^{-}$) were analysed by ion chromatography (IC). Total alkalinity 


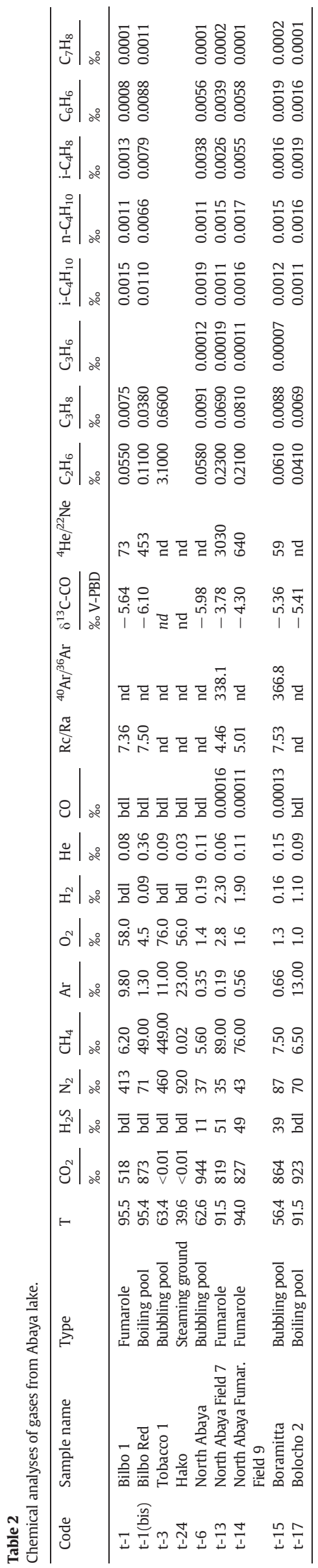

was determined by acidimetric titration (AT) with $\mathrm{HCl} 0.5 \mathrm{~N}$ using a Methrom 794 Basic Titrino. Boron was analysed using the Azomethine- $\mathrm{H}$ method (Bencini, 1985) by molecular spectrophotometry (MS) Philips Unicam SP6-350. The latter instrument was also used for $\mathrm{SiO}_{2}$ whose analysis was carried out in a diluted solution (1/10) prepared in the field. The analytical errors for AT, IC and MS analyses were $\leq 5 \%$.

The isotopic analyses were performed using a Finnigan Delta Plus mass spectrometer coupled with a Finnigan HDO automatic equilibration device. The oxygen $\delta^{18} \mathrm{O}$ determinations were carried out on $\mathrm{CO}_{2}$ gas equilibrated with the water sample (Epstein and Mayeda, 1953); the hydrogen $\delta \mathrm{D}$ measurements on ultrapure hydrogen equilibrated with water sample by means of Pt-catalyser (Coleman et al., 1982 ). The analytical errors were: $\pm 1 \%$ ofor $\delta \mathrm{D}-\mathrm{H}_{2} \mathrm{O}$ and $\pm 0.08 \%$ ofor $\delta^{18} \mathrm{O}-\mathrm{H}_{2} \mathrm{O}$.

Inorganic gases $\left(\mathrm{N}_{2}, \mathrm{Ar}+\mathrm{O}_{2}, \mathrm{H}_{2}\right.$, He and $\left.\mathrm{CO}\right)$ in the flask headspace were analysed using a gas chromatograph equipped with a $10 \mathrm{~m}$ long $5 \mathrm{~A}$ molecular sieve column and a thermal conductivity detector (TCD). Argon and $\mathrm{O}_{2}$ were analysed using a gas chromatograph equipped with a $30 \mathrm{~m}$ long capillary molecular sieve column and a TCD. A gas chromatograph equipped with a 10 -m-long stainless steel column packed with Chromosorb PAW 80/100 mesh coated with 23\% SP 1700 and a flame ionization detector (FID) was used to analyse $\mathrm{CH}_{4}$ and light hydrocarbons. In the liquid phase, $\mathrm{CO}_{2}$ (as $\mathrm{CO}_{3}^{2-}$ ) and $\mathrm{H}_{2} \mathrm{~S}$ (as $\mathrm{SO}_{4}^{2-}$ ) were analysed by AT and IC, respectively.

Gas samples for the analysis of the ${ }^{13} \mathrm{C} /{ }^{12} \mathrm{C}$ isotopic ratio in $\mathrm{CO}_{2}$ (as $\delta^{13} \mathrm{C}^{-\mathrm{CO}_{2}} \%$ 。 vs. V-PDB) were analysed using a Finnigan Delta-S mass spectrometer after standard extraction and purification procedures (Evans et al., 1998). The analytical error and the reproducibility were $\pm 0.05 \%$ o and $\pm 0.1 \%$, respectively.

The isotopic analyses of noble gases were conducted using a Thermo Fisher Helix SFT Noble Gas mass spectrometer, following methods reported previously (Darrah and Poreda, 2012; Darrah et al., 2013; Hunt et al., 2012). The He isotopic ratios are expressed as $\mathrm{R} / \mathrm{Ra}$, where $\mathrm{R}$ is the ${ }^{3} \mathrm{He} /{ }^{4} \mathrm{He}$ measured ratio, and $\mathrm{Ra}$ is the ${ }^{3} \mathrm{He} /{ }^{4} \mathrm{He}$ ratio in the air $\left(1.39 \times 10^{-6}\right.$; Mamyrin and Tolstikhin, 1984). Noble gas isotopic standard errors were approximately \pm 0.0092 times the ratio of air (or $1.26 \times 10^{-8}$ ) for ${ }^{3} \mathrm{He} /{ }^{4} \mathrm{He}$ ratio and $< \pm 0.476 \%$ and $< \pm 0.734 \%$ for ${ }^{20} \mathrm{Ne} /{ }^{22} \mathrm{Ne}$ and ${ }^{21} \mathrm{Ne} /{ }^{22} \mathrm{Ne}$, respectively, less than $\pm 0.763 \%$ and $0.537 \%$ for ${ }^{38} \mathrm{Ar} /{ }^{36} \mathrm{Ar}$ and ${ }^{40} \mathrm{Ar} /{ }^{36} \mathrm{Ar}$, respectively (higher than typical because of interferences from $\mathrm{C}_{3} \mathrm{H}_{8}$ on mass $=36$ and 38).

\section{Results}

\subsection{Geochemistry of waters}

The chemical and isotopic compositions of all the water samples collected in 1972, 1976, 2000 and 2015 are reported in Table 1. The main components in the liquid phase are plotted in the Langelier and Ludwig (1942) diagram of Fig. 3 for classification. The water samples are divided according to the area of fluid discharge and/or the type of sample. The diagram shows that all thermal springs, most cold springs, rivers and the Abaya Lake, are $\mathrm{Na}-\mathrm{HCO}_{3}$-rich waters. The diagram shows that Abaya \#6 and samples from Bolocho are virtually without $\mathrm{Ca}$ and $\mathrm{Mg}$ ions in solution, with a slight enrichment in $\mathrm{Na}$ and $\mathrm{Cl}$ for sample \#6. The salinity of cold samples, rivers and the Lake Abaya never exceeds $1000 \mathrm{mg} / \mathrm{L}$ of total dissolved solids (TDS) whereas the TDS of most thermal springs is in the range of 1000-2500 mg/L. Exceptions are the aforementioned Abaya \#6 spring, the Bolocho samples, which are the hottest springs in the area, and exhibit TDS in the range $4000-4800 \mathrm{mg} / \mathrm{L}$.

To elucidate the main water-interaction processes in the area, plots of $\mathrm{Na}+\mathrm{K}$ vs. $\mathrm{HCO}_{3}+\mathrm{CO}_{3}, \mathrm{Na}+\mathrm{K}$ vs. temperature, $\mathrm{Na}$ vs. $\mathrm{Cl}$ and $\log (\mathrm{Na} / \mathrm{K})$ vs. temperature are shown in Fig. 4. The $\mathrm{Na}+\mathrm{K}$ vs. $\mathrm{HCO}_{3}+\mathrm{CO}_{3}$ diagram (top left) plots the elements whose sum represents $>90 \%$ of TDS for most samples. Apart from the Abaya spring \#6, which could not be located, and the Bolocho thermal springs (\#sp-14, 


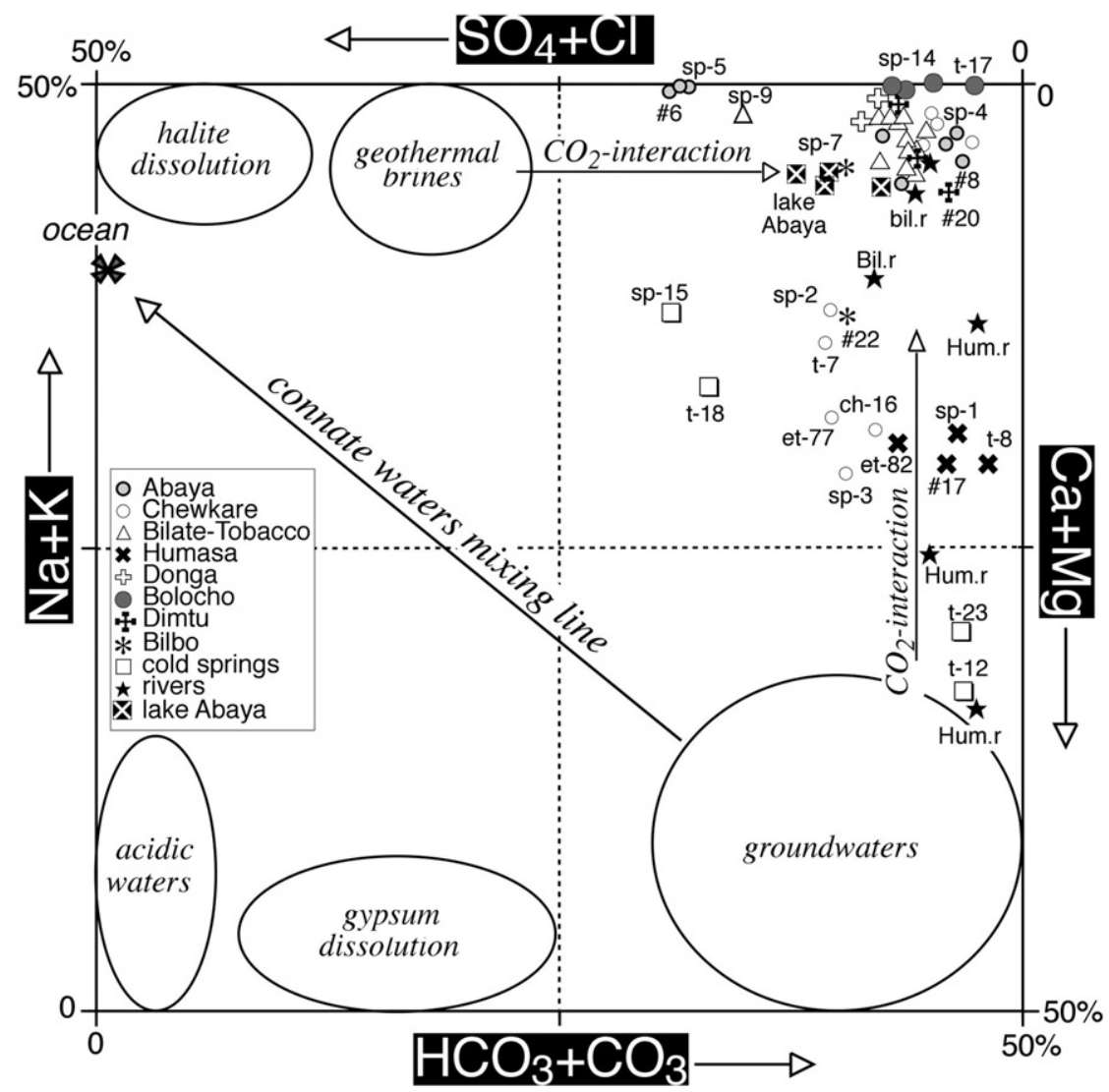

Fig. 3. Classification Langelier and Ludwig (1942) diagram for the samples investigated according to emergence area.

\#t-16 and \#t-17) that have an excess of $\mathrm{Na}+\mathrm{K}$, all the other water discharges are clustering along the stoichiometric line $(r=1)$, which suggests a common evolutionary trend of all waters in the area. By plotting the samples in the $\mathrm{Na}+\mathrm{K}$ vs. temperature diagram (top right), they spread from low concentrations in cold samples and rivers towards higher concentrations, in a sector where two different mixing mechanisms with cold shallow waters seem evident: one with the Abaya \#6 and Bolocho waters and the other with those from Bilate-Tobacco plantation. Although in these two diagrams the Abaya \#6 and Bolocho samples seem to belong to a common aquifer, the $\mathrm{Na} v \mathrm{vs}$. $\mathrm{Cl}$ plot (Fig. 4, bottom left) clearly suggests that the Abaya \#6 has $\mathrm{Cl}$ in excess with respect to all the other samples, where the $\mathrm{Na}$ ion is prevalently saturated by the $\mathrm{HCO}_{3}$ ion. Finally, in the $\log (\mathrm{Na} / \mathrm{K})$ vs. temperature diagram (Fig. 4, bottom right; after Fournier, 1991), that will be discussed later on, such clear separation between the Abaya \#6 aquifer and all the other samples is further confirmed.

In terms of $\delta^{18} \mathrm{O}$ and $\delta \mathrm{D}$ values, all the available data gathered in the four described sampling campaigns are plotted in Fig. 5 (Craig, 1961). The diagram includes the Global Meteoric Line (GMWL: Craig, 1961), the Addis Ababa Meteoric Line (AAML; Craig et al., 1977), the points of maximum, minimum, and average rainfall at Addis Ababa (Levin et al., 2009), as well as a rain sample collected in 1976 at Soddo town at an altitude of about $2000 \mathrm{~m}$ and located about $20 \mathrm{~km} \mathrm{NW}$ of Lake Abaya (Craig et al., 1977). Most waters cluster between the GMWL and the AAML, with values varying from $-2.0 \%$ o to $-14.0 \%$ V-SMOW for $\delta \mathrm{D}$ and from $-2.0 \%$ o to $-3.5 \%$ 。 $\mathrm{V}$-SMOW for $\delta^{18} \mathrm{O}$, respectively. As expected, the Abaya Lake sample(s) experienced evaporation and lie to the right of the GMWL and AAML, as they are distributed along an evaporation line of equation $\delta \mathrm{D}=5.5 \delta^{18} \mathrm{O}+8.5$. The Bolocho and the Hamesa and Bilate River samples are also lying along the similar evaporation lines.

The Abaya \#6 (i.e.: \#et-72, \#sp-5) and Abaya \#7 samples behave differently. The first one was described as a thermal spring and submerged by the lake between 2000 and 2002, while the second one was depicted in 1977 as a frying pan type emission (boiling and/or gas bubbling pool; Craig et al., 1977) at $91{ }^{\circ} \mathrm{C}$. The latter was located at higher elevation with respect to sample \#6. In 2015, this emission was seen similar to a fumarolic discharge then a frying pan type emission. The two emissions were very close to each other and their isotope signature can be related, as can be seen in Fig. 5, where the sample \#7 (or \#et-73) likely represents an evaporated condensate of sample \#6. Nevertheless, the Abaya sample \#6 clearly shows a markedly positive 1.5-2.0\% V-SMOW shift with respect to all the other thermal samples.

In terms of minor elements and considering that some water samples have elevated concentrations of $\mathrm{F}^{-}(>40 \mathrm{mg} / \mathrm{L})$ typical of other areas in the EARS (Gizaw, 1996), as shown in the $\mathrm{Cl}^{-}$vs. $\mathrm{F}^{-}$diagram of Fig. 6 the $\mathrm{Cl} / \mathrm{F}$ ratio varies from 1.5 for the northernmost sample of Dimtu to about 40 for some thermal springs of Chawkare. Not surprisingly the average ratio $(\approx 15)$ approaches that of Abaya Lake $(\approx 11)$, since it is the natural collector of such thermal water emissions. This diagram better allows us to distinguish the different aquifers in the area that cannot clearly be identified otherwise due to similar main chemical $\mathrm{Na}-\mathrm{HCO}_{3}$ composition and isotopic signature.

As far as the silica concentration is concerned, both the 1973 and $2000 \mathrm{SiO}_{2}$ concentrations were overestimated as already pointed out by Craig et al. (1977) for the samples of 1973. For this reason the $\mathrm{SiO}_{2}-$ temperature diagram of Fig. 7 only reports those measured in 1977 and 2015. Fig. 7 (after Fournier, 1991) shows that the $\mathrm{SiO}_{2}$ solubility in thermal waters is likely controlled by amorphous silica and/or one of the alteration phases of quartz (either opal or chalcedony). This result is also confirmed by the calculation of saturation indexes computed with the PHREEQC speciation code of Parkhurst and Appelo (1999) and shown in Table 3. As will be discussed further, these results indicate that geothermometric estimations using the quartz geothermometer cannot be applied here. 

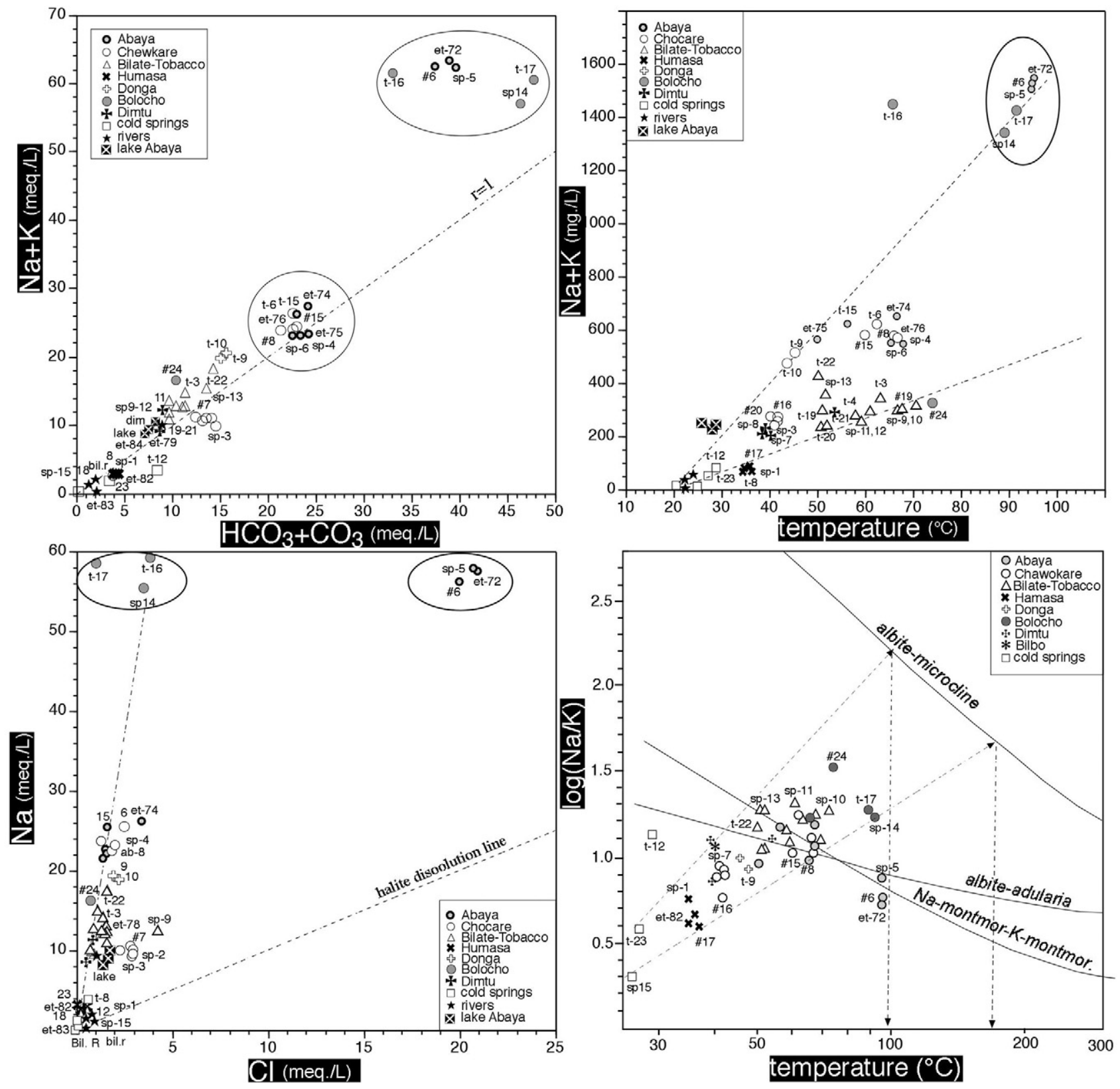

Fig. 4. Multiple: $(\mathrm{Na}+\mathrm{K})$ vs. $\left(\mathrm{HCO}_{3}+\mathrm{CO}_{3}\right),(\mathrm{Na}+\mathrm{K})$ vs. temperature, $\mathrm{Na}$ vs. $\mathrm{Cl}$ and $\log (\mathrm{Na} / \mathrm{k})$ vs. temperature (Fournier, 1991$)$ diagrams (see text).

\subsection{Geochemistry of gases}

Although the previous reports from this area included analyses of water chemistry and select gas analyses mentioned above, there has not been a comprehensive analysis of gas chemistry and isotopic composition conducted to date in this area. Consequently, sampling of the gases associated with springs and fumaroles was the primary aim of our 2015 campaign. In spite of these objectives, one of the major field observations from this work was that, contrary to what was reported by the two UN missions, $\mathrm{CO}_{2}$ degassing from thermal springs and fumaroles in the Abaya area is actually low with respect to other Ethiopian geothermal areas (Lee et al., 2016). Most thermal springs have low to-very-low associated gas phases, which often display intermittent discharge, which is typical of solubilised nitrogen that exsolves following water depressurization at the surface manifestation. All of the gas data obtained, including major and trace components, and isotopic parameters $\left(\delta^{13} \mathrm{C}-\mathrm{CO}_{2}\right), \mathrm{CO}_{2} /{ }^{3} \mathrm{He}$, and ${ }^{3} \mathrm{He} /{ }^{4} \mathrm{He}$ ratios (as $\mathrm{R} / \mathrm{Ra}$ ), and other noble gases $(\mathrm{Ne}, \mathrm{Ar})$ are shown in Table 2.
Samples \#t-1 (Bilbo), \#t-3 (Bilate), \#t-17 (Bolocho) and \#t-24 (Hako) contained $>5 \%$ oxygen, which suggests strong contamination by air, likely because of the difficult sampling conditions. These results are also likely impacted by the very low gas emissions and resulting difficulty to properly catch the rising bubbles without air contamination.

The remaining samples displayed relatively low amounts of air contamination. The Bilate-Tobacco \#t-3 sample has about $50 \%$ methane and $50 \%$ nitrogen, clearly suggesting a very shallow origin, likely resulting from the presence of fermented organic matter. The remaining \#t1(bis) sample from Bilbo (a boiling pool) and \#t-6, \#t-13, \#t-14 and \#t-15 from the Chewkare graben (north of Abaya) are the only $\mathrm{CO}_{2}$ dominated samples. The two described groups are clearly recognised in the $\mathrm{N}_{2} / 100-\mathrm{He}^{*} 10-\mathrm{Ar}$ diagram of Fig. 8 (Giggenbach et al., 1983), where the position of the first group near the air saturated water (ASW) and not near the composition of air, as one would expect, suggests that nitrogen is derived by the exsolution of solubilised gas from air-saturated water. While these values do suggest a low ratio of magmatically derived gases relative to shallow air-saturated water 


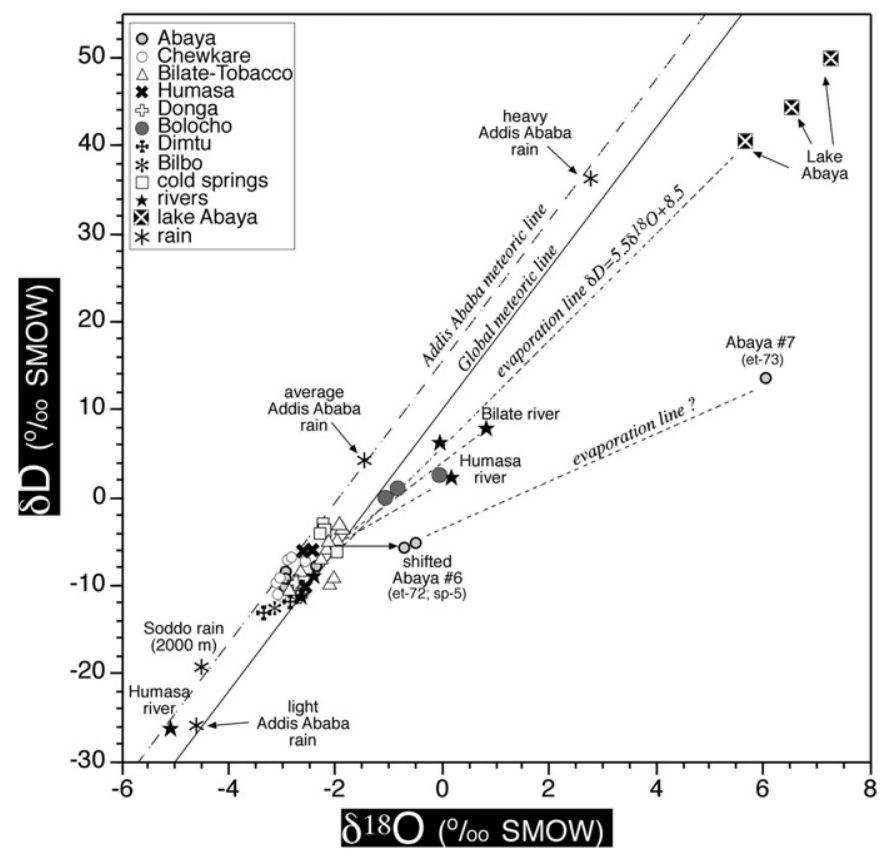

Fig. 5. Diagram of $\delta^{18} \mathrm{O}$ vs. $\delta \mathrm{D}$ (Craig, 1961) for the samples investigated. All data reported in Table 1 have been plotted according to emergence area.

components, because ASW has more argon (more soluble) than nitrogen with respect to air, these observations are inconsistent with air contamination during sampling.

The carbon isotopic values for these samples vary in a narrow range from $-3.78 \%$ onear Lake Abaya up to $-6.1 \%$ at Bilbo. This range of variation is typical of mantle-derived carbon dioxide (Rollinson, 1993; Deines, 2002) and is in agreement with what was suggested by the helium isotopic values from this study and other reports from many other areas along the Ethiopian Rift (Lee et al., 2016).

The new noble gas (i.e., ${ }^{3} \mathrm{He} /{ }^{4} \mathrm{He}$ and $\mathrm{CO}_{2} /{ }^{3} \mathrm{He}$ ) ratios are consistent with our interpretation of the carbon isotopic composition of $\mathrm{CO}_{2}$.

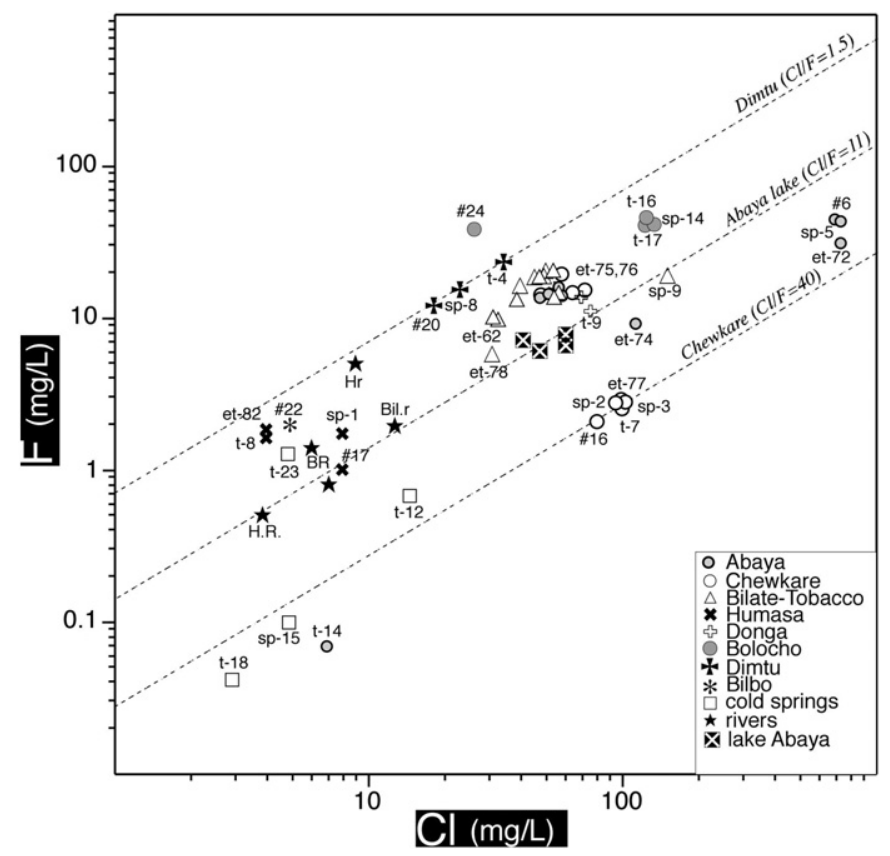

Fig. 6. Correlation diagram of $\mathrm{F} \mathrm{vs.} \mathrm{Cl}$ for the water samples investigated with dotted lines of different $\mathrm{Cl} / \mathrm{F}$ ratios.

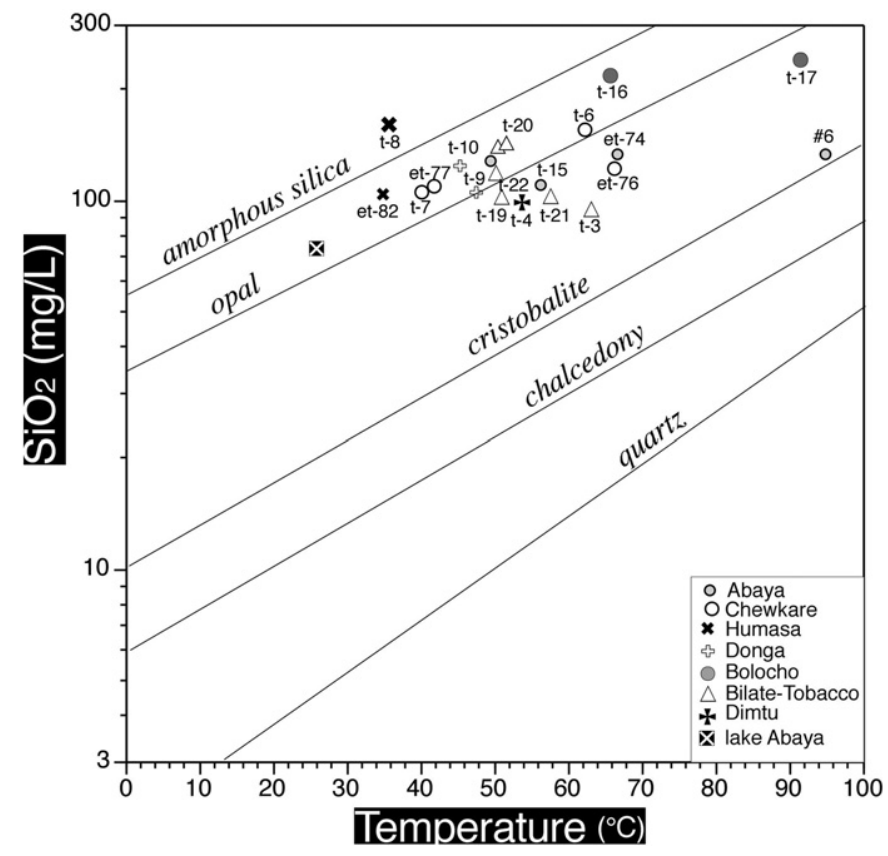

Fig. 7. Silica vs. temperature diagram showing solubility lines of different $\mathrm{SiO}_{2}$ mineral phases.

Both parameters confirm the presence of mantle-derived gas emissions as reported by Craig et al. (1977). In particular, the R/Ra values vary from 4.46Ra near the Lake Abaya, up to 7.5Ra at Bilbo and Bolocho sites, suggesting a significant contribution of mantle-derived ${ }^{3} \mathrm{He}$ $(\mathrm{R} / \mathrm{Ra}=8 \mathrm{in} \mathrm{MORB})$ in each sampling area. Consistent with these observations, the $\mathrm{CO}_{2} /{ }^{3} \mathrm{He}$ range from $3.70 \times 10^{8}$ at Bilbo in a relatively low $\mathrm{CO}_{2}$ sample, to $6.59 \times 10^{10}$ at Bilbo Red. Although there is considerable range in these values, which seem to straddle the typical MORB-like composition $\left(\sim 2 \times 10^{9}\right)$, likely reflecting variable degrees of gas-water interactions, these observations are largely consistent with the range observed for mantle-derived $\mathrm{CO}_{2}$ and ${ }^{3} \mathrm{He}$ (Ballentine et al., 2002).

While one might anticipate resolvable mantle contributions for $\mathrm{Ne}$ and $\mathrm{Ar}$, all of these samples display neon and argon isotopes within 5 and $20 \%$ of the air-saturated water values for these parameters. These results indicate that the isotopic composition of neon and argon is dominated by shallow water-derived components as is common in many geothermal systems (Craig et al., 1978).

\section{Discussion}

\subsection{Origin of the deep fluids}

The area north of the Lake Abaya displays surface discharges of different types that can be grouped, in terms of geothermal hierarchy, as follows:

1) boiling (or near-boiling) steam vents (or fumaroles) without relevant associated gas phases (e.g., \#7 or \#et-73 or \#t-14 near Lake Abaya; \#22 or \#t-1 at Bilbo, Table 1);

2) boiling or near-boiling water-pools (e.g. \#t-17 at Bolocho, Table 1);

3) thermal springs, with or without associated gas emission (or at least low volumes of emissions), either $\mathrm{CO}_{2}$ or $\mathrm{N}_{2}$-rich;

4) steaming ground at Hako $\left(39.6{ }^{\circ} \mathrm{C}\right)$ where in 1972 a temperature of $90{ }^{\circ} \mathrm{C}$ was reported by the UN mission, but not sampled during that or subsequent surveys and could not be found during this study in 2015.

Among the thermal springs, Abaya \#6 (\#et-72, \#eth-12, \#sp-5 in Table 1) deserves special attention. Although this spring is not presently 
Table 3

Saturation indexes (in bold saturated minerals) of relevant mineral phases and calculated $\mathrm{Pco}_{2}$ (atm).

\begin{tabular}{|c|c|c|c|c|c|c|c|c|c|c|c|c|c|c|c|c|c|c|c|c|}
\hline Code & Sample name & $\mathrm{T}^{\circ} \mathrm{C}$ & $\mathrm{pH}$ & si__CO $(\mathrm{g})$ & $\mathrm{PcO}_{2}(\mathrm{~g})$ & Antigorite & $S(a)$ & Tremolite & Anthophyllite & Sepiolite & Talc & Lizardite & Chrysotile & Diopside & Dolomite & Magnesite & Forsterite & Calcite & Quartz & Chalcedony \\
\hline \#6 & Abaya 6 & 95.0 & 9.60 & -2.994 & 0.001 & 112.46 & 16.63 & 10.65 & 7.39 & 6.65 & 6.39 & 6.08 & 5.59 & 1.65 & 0.39 & 1.14 & 0.32 & 0.00 & -0.20 & -0.43 \\
\hline et-72 & Abaya 6 & 95.0 & 9.58 & -2.619 & 0.002 & 90.33 & & 6.80 & 3.60 & 4.22 & 4.67 & 4.72 & 4.23 & 0.59 & 0.45 & 1.18 & -0.53 & 0.01 & -0.38 & -0.61 \\
\hline$\# 8$ & Abaya 8 & 65.5 & 7.20 & -0.207 & 0.621 & -3.06 & 13.34 & -3.54 & -8.26 & -0.01 & 0.64 & -1.30 & -1.84 & -2.60 & 1.80 & 1.70 & -5.53 & 0.95 & 0.67 & 0.42 \\
\hline et-74 & Abaya 8 & 67.0 & 6.95 & 0.083 & 1.211 & -38.73 & & -8.35 & -13.57 & -3.18 & -1.69 & -3.52 & -4.05 & -3.83 & 1.17 & 1.25 & -6.95 & 0.76 & 0.61 & 0.37 \\
\hline sp-6 & Sp-6 (Wache) & 67.0 & 7.50 & -0.434 & 0.368 & -33.34 & & -8.33 & -12.44 & -2.38 & -1.15 & -3.19 & -3.73 & -4.10 & -0.35 & 0.77 & -6.77 & -0.27 & 0.73 & 0.48 \\
\hline et-75 & Abaya 10 & 50.0 & 6.76 & 0.119 & 1.316 & -71.01 & & -13.17 & -18.71 & -5.24 & -3.51 & -5.59 & -6.15 & -5.36 & 0.59 & 1.03 & -8.79 & 0.48 & 0.78 & 0.51 \\
\hline $\mathrm{t}-15$ & Boramitta & 56.4 & 6.59 & 0.277 & 1.891 & -88.76 & & -15.67 & -21.34 & -7.18 & -4.82 & -6.67 & -7.22 & -5.95 & 0.11 & 0.70 & -9.31 & 0.30 & 0.65 & 0.39 \\
\hline$\# 15$ & Chewkare 15 & 60.0 & 7.00 & -0.055 & 0.880 & -40.03 & & -8.59 & -13.81 & -2.91 & -1.62 & -3.62 & -4.17 & -4.00 & 0.99 & 1.22 & -7.22 & 0.65 & 0.72 & 0.46 \\
\hline et-76 & Chewkare 15 & 66.5 & 6.80 & 0.156 & 1.432 & -62.39 & & -12.30 & -17.12 & -5.23 & -3.22 & -4.99 & -5.53 & -5.05 & 0.18 & 0.86 & -7.94 & 0.16 & 0.59 & 0.34 \\
\hline sp-4 & Sp-4 (Boramita) & 66.0 & 7.60 & -0.554 & 0.279 & 10.88 & & -3.34 & -6.15 & 1.21 & 1.55 & -0.43 & -0.97 & -2.95 & 0.68 & 1.62 & -4.94 & -0.09 & 0.69 & 0.44 \\
\hline$t-6$ & North of Abaya & 62.6 & 6.60 & 0.307 & 2.027 & -74.64 & & -13.05 & -18.68 & -5.78 & -3.74 & -5.78 & -6.33 & -5.17 & 0.34 & 0.77 & -8.61 & 0.44 & 0.73 & 0.48 \\
\hline$\# 16$ & Chewkare 16 & 42.0 & 7.20 & -0.564 & 0.273 & -16.70 & & -5.75 & -11.11 & -0.51 & -0.07 & -2.22 & -2.80 & -3.38 & 1.72 & 1.71 & -6.77 & 0.96 & 0.82 & 0.55 \\
\hline et-77 & Chewkare 16 & 42.0 & 7.22 & -0.574 & 0.267 & -16.42 & & -5.93 & -11.17 & -0.59 & -0.12 & -2.19 & -2.77 & -3.45 & 1.69 & 1.73 & -6.74 & 0.92 & 0.79 & 0.52 \\
\hline sp-2 & Sp-2 (Boramita) & 41.0 & 7.50 & -0.852 & 0.141 & -46.93 & & -13.00 & -15.62 & -3.07 & -2.00 & -4.11 & -4.69 & -6.04 & -1.41 & 0.84 & -8.05 & -1.29 & 0.81 & 0.54 \\
\hline sp-3 & Sp-3 (Boramita) & 42.0 & 7.60 & -0.899 & 0.126 & -28.07 & & -7.93 & -12.70 & -1.40 & -0.75 & -2.93 & -3.51 & -4.13 & 0.25 & 1.12 & -7.25 & 0.08 & 0.84 & 0.57 \\
\hline $\mathrm{t}-7$ & $\mathrm{~N}$ of Abaya spring & 40.6 & 7.22 & -0.618 & 0.241 & -18.18 & & -7.89 & -11.48 & -0.71 & -0.22 & -2.31 & -2.89 & -4.37 & 0.78 & 1.69 & -6.85 & 0.04 & 0.80 & 0.53 \\
\hline$\# 19$ & Bilate & 68.0 & 7.40 & -0.699 & 0.200 & 10.72 & 13.61 & -1.99 & -6.40 & 0.84 & 1.35 & -0.42 & -0.96 & -2.18 & 1.25 & 1.49 & -4.86 & 0.61 & 0.58 & 0.34 \\
\hline sp-9 & Sp-9 (Bilate) & 67.0 & 8.20 & -1.463 & 0.034 & 1.12 & & -2.90 & -7.70 & 0.20 & 0.83 & -1.03 & -1.56 & -2.37 & -0.50 & 0.52 & -5.30 & -0.18 & 0.63 & 0.38 \\
\hline $\mathrm{t}-3$ & Tobacco plantation 1 & 63.4 & 7.28 & -0.545 & 0.285 & -39.91 & & -8.67 & -14.30 & -3.64 & -2.01 & -3.58 & -4.12 & -3.84 & 0.39 & 0.79 & -7.04 & 0.46 & 0.49 & 0.24 \\
\hline sp-10 & Sp-10 (Bilate) & 73.0 & 8.30 & -1.556 & 0.028 & 17.87 & & -0.87 & -5.36 & 1.12 & 1.66 & 0.05 & -0.48 & -1.76 & -0.20 & 0.70 & -4.40 & -0.08 & 0.50 & 0.25 \\
\hline sp-11 & Sp-11 (Bilate) & 61.0 & 8.00 & -1.272 & 0.053 & -30.56 & & -7.40 & -12.60 & -2.37 & -1.16 & -3.02 & -3.57 & -3.63 & -1.00 & 0.22 & -6.77 & -0.35 & 0.64 & 0.39 \\
\hline sp-12 & Sp-12 (Bilate) & 59.0 & 8.00 & -1.338 & 0.046 & -24.62 & & -6.21 & -11.90 & -1.91 & -0.83 & -2.65 & -3.20 & -3.20 & -0.52 & 0.35 & -6.57 & 0.00 & 0.63 & 0.37 \\
\hline$t-19$ & Tobacco plantation 2 & 51.1 & 7.22 & -0.703 & 0.198 & -53.31 & & -9.92 & -16.36 & -4.08 & -2.57 & -4.47 & -5.03 & -4.20 & 0.22 & 0.61 & -7.99 & 0.52 & 0.68 & 0.42 \\
\hline$t-20$ & Tobacco plantation 4 & 51.5 & 7.17 & -0.655 & 0.221 & -52.84 & & -9.57 & -15.87 & -3.62 & -2.30 & -4.45 & -5.02 & -4.17 & 0.05 & 0.56 & -8.01 & 0.41 & 0.81 & 0.55 \\
\hline $\mathrm{t}-21$ & Tobacco plantation 5 & 58.0 & 7.28 & -0.651 & 0.223 & -40.44 & & -8.44 & -14.38 & -3.34 & -1.90 & -3.64 & -4.19 & -3.79 & 0.42 & 0.77 & -7.24 & 0.53 & 0.59 & 0.33 \\
\hline et-78 & Bilate-Tobacco & 51.0 & 7.60 & -0.938 & 0.115 & -25.44 & & -5.66 & -11.96 & -1.40 & -0.62 & -2.74 & -3.30 & -3.05 & 0.68 & 0.87 & -6.88 & 0.72 & 0.79 & 0.53 \\
\hline sp-13 & Sp-13 (Methincho) & 52.0 & 8.30 & -1.561 & 0.027 & -4.80 & & -4.33 & -8.95 & 0.25 & 0.64 & -1.44 & -2.01 & -3.01 & -0.56 & 0.66 & -5.98 & -0.31 & 0.77 & 0.51 \\
\hline$t-22$ & Metincho (Bolocho) & 50.3 & 7.81 & -1.059 & 0.087 & 2.34 & & -2.85 & -8.11 & 0.75 & 1.01 & -1.00 & -1.56 & -2.46 & 1.19 & 1.39 & -5.71 & 0.71 & 0.74 & 0.48 \\
\hline \#24 & Bolocho (Wogeri) & 74.0 & 8.40 & -1.690 & 0.020 & 58.04 & & 4.15 & -0.22 & 3.66 & 3.70 & 2.59 & 2.06 & -0.28 & 1.46 & 1.55 & -2.60 & 0.72 & 0.25 & 0.00 \\
\hline sp-14 & Sp-14 (Bolocho) & 89.0 & 8.20 & -0.747 & 0.179 & 8.35 & & -0.28 & -5.56 & 0.62 & 1.40 & -0.54 & -1.04 & -1.32 & 0.61 & 0.79 & -4.49 & 0.59 & 0.63 & 0.40 \\
\hline$t-16$ & Bolocho & 65.8 & 7.30 & -0.123 & 0.753 & -41.81 & & -7.65 & -13.38 & -2.71 & -1.46 & -3.74 & -4.28 & -3.61 & 0.60 & 0.85 & -7.20 & 0.60 & 0.84 & 0.59 \\
\hline$t-17$ & Bolocho 2 & 91.5 & 7.70 & -0.193 & 0.641 & 23.37 & & 1.05 & -3.21 & 1.90 & 2.38 & 0.41 & -0.10 & -1.14 & 1.72 & 1.58 & -3.82 & 0.90 & 0.64 & 0.41 \\
\hline$\# 17$ & Humasa hot spring & 37.0 & 6.40 & -0.424 & 0.377 & -126.72 & 10.56 & -20.83 & -27.20 & -9.39 & -6.83 & -9.11 & -9.70 & -7.55 & -1.94 & -0.32 & -11.52 & -0.64 & 0.90 & 0.63 \\
\hline et- 82 & Humasa hot spring & 35.0 & 6.90 & -0.847 & 0.142 & -87.14 & & -15.34 & -21.71 & -6.24 & -4.46 & -6.64 & -7.23 & -5.99 & -0.96 & 0.19 & -9.91 & -0.16 & 0.85 & 0.58 \\
\hline $\mathrm{sp}-1$ & Sp-1 (Humasa) & 35.0 & 7.20 & -1.113 & 0.077 & -57.97 & & -10.51 & -17.02 & -3.35 & -2.37 & -4.83 & -5.43 & -4.62 & -0.41 & 0.43 & -8.75 & 0.15 & 1.00 & 0.72 \\
\hline$t-8$ & Humasa spring & 36.2 & 6.36 & -0.438 & 0.365 & -127.07 & & -20.52 & -26.93 & -9.02 & -6.63 & -9.15 & -9.74 & -7.50 & -2.09 & -0.40 & -11.61 & -0.71 & 1.03 & 0.75 \\
\hline$t-9$ & East Abaya 1 (Donga) & 47.9 & 7.87 & -1.097 & 0.080 & -10.92 & & -4.67 & -10.28 & -0.45 & 0.10 & -1.83 & -2.40 & -2.92 & 0.89 & 1.18 & -6.32 & 0.64 & 0.70 & 0.44 \\
\hline$t-10$ & East Abaya 2 (Donga) & 45.5 & 7.79 & -1.051 & 0.089 & -19.81 & & -4.74 & -11.40 & -0.85 & -0.28 & -2.40 & -2.97 & -2.77 & 1.11 & 1.05 & -6.79 & 1.00 & 0.81 & 0.54 \\
\hline \#22 & Bilbo & 95.0 & 7.60 & -1.496 & 0.032 & 34.45 & & 0.97 & -3.01 & 1.17 & 2.12 & 1.17 & 0.67 & -1.05 & 0.04 & 0.78 & -3.07 & 0.00 & 0.13 & -0.10 \\
\hline sp-7 & Bilbo & 40.0 & 7.66 & -1.197 & 0.064 & -31.53 & & -6.69 & -13.31 & -1.65 & -0.96 & -3.15 & -3.73 & -3.41 & 0.53 & 0.82 & -7.45 & 0.67 & 0.85 & 0.58 \\
\hline$\# 20$ & Dimtu springs & 39.5 & 7.00 & -0.603 & 0.249 & -83.60 & & -14.56 & -20.97 & -6.03 & -4.25 & -6.40 & -6.99 & -5.70 & -0.51 & 0.36 & -9.63 & 0.10 & 0.83 & 0.56 \\
\hline sp-8 & Dimtu springs & 39.0 & 7.90 & -1.418 & 0.038 & -11.10 & & -3.55 & -10.19 & 0.27 & 0.43 & -1.88 & -2.47 & -2.54 & 0.90 & 1.01 & -6.65 & 0.86 & 0.91 & 0.64 \\
\hline$t-4$ & Dimtu (well) & 53.8 & 8.00 & -1.410 & 0.039 & -28.39 & & -5.58 & -12.79 & -2.25 & -1.14 & -2.89 & -3.45 & -2.74 & 0.20 & 0.38 & -6.85 & 0.72 & 0.61 & 0.35 \\
\hline$t-12$ & Shinkeko well & 28.8 & 7.16 & -0.809 & 0.155 & & & & & & & & & & 0.88 & 1.09 & & 0.80 & & \\
\hline sp-15 & Gola & 20.0 & 8.60 & -3.741 & 0.000 & -35.00 & & -8.36 & -15.93 & -2.70 & -1.84 & -3.38 & -4.00 & -3.83 & -2.73 & -0.84 & -8.06 & -0.82 & 0.56 & 0.27 \\
\hline$t-18$ & Soddo well & 21.1 & 7.01 & -2.322 & 0.005 & & & & & & & & & & -5.51 & -2.20 & & -2.25 & & \\
\hline$t-23$ & Maze well & 27.2 & 7.46 & -1.459 & 0.035 & & & & & & & & & & 0.01 & 1.04 & & -0.01 & & \\
\hline A.L. & Al (Abaya lake) & 28.0 & 8.60 & -2.260 & 0.006 & -43.07 & & -11.23 & -17.77 & -4.66 & -3.02 & -3.82 & -4.42 & -4.67 & -0.52 & 0.43 & -7.99 & 0.07 & 0.18 & -0.11 \\
\hline$t-11$ & Lake Abaya & 29.4 & 8.53 & -2.146 & 0.007 & & & & & & & & & & 1.76 & 1.40 & & 1.37 & & \\
\hline $\mathrm{Hr}$ & Humasa river & 20.0 & 8.70 & -2.599 & 0.003 & 37.26 & & 2.64 & -4.46 & 4.28 & 3.24 & 1.10 & 0.48 & -0.88 & 1.90 & 1.59 & -5.18 & 1.38 & 0.87 & 0.58 \\
\hline et-83 & Humasa river & 20.0 & 7.85 & -2.155 & 0.007 & -62.16 & & -12.20 & -19.76 & -4.83 & -3.46 & -5.08 & -5.71 & -4.95 & -0.75 & 0.15 & -9.21 & 0.16 & 0.61 & 0.32 \\
\hline $\mathrm{HR}$ & HR (Humasa river) & 24.0 & 7.90 & -2.093 & 0.008 & -58.41 & & -12.53 & -19.76 & -5.39 & -3.70 & -4.80 & -5.42 & -4.98 & -0.49 & 0.32 & -8.82 & 0.23 & 0.34 & 0.05 \\
\hline et-62 & Bilate river 1 & 20.0 & 8.40 & -2.035 & 0.009 & -15.53 & & -3.76 & -11.64 & 0.42 & 0.26 & -2.22 & -2.85 & -2.59 & 0.98 & 0.93 & -7.45 & 1.11 & 1.04 & 0.75 \\
\hline Bil.r. & Bil.R (Bilate river) & 24.0 & 7.20 & -1.470 & 0.034 & -132.13 & & -22.69 & -30.18 & -11.19 & -8.10 & -9.42 & -10.04 & -7.87 & -2.35 & -0.67 & -11.94 & -0.63 & 0.45 & 0.16 \\
\hline $\mathrm{BR}$ & $\mathrm{BR}$ (Bedesa river) & 23.0 & 7.40 & -1.809 & 0.016 & -86.59 & & -13.38 & -20.17 & -3.81 & -3.15 & -6.72 & -7.34 & -5.69 & -3.02 & -0.82 & -10.54 & -1.14 & 1.58 & 1.29 \\
\hline
\end{tabular}

Same codes as Table 1. 


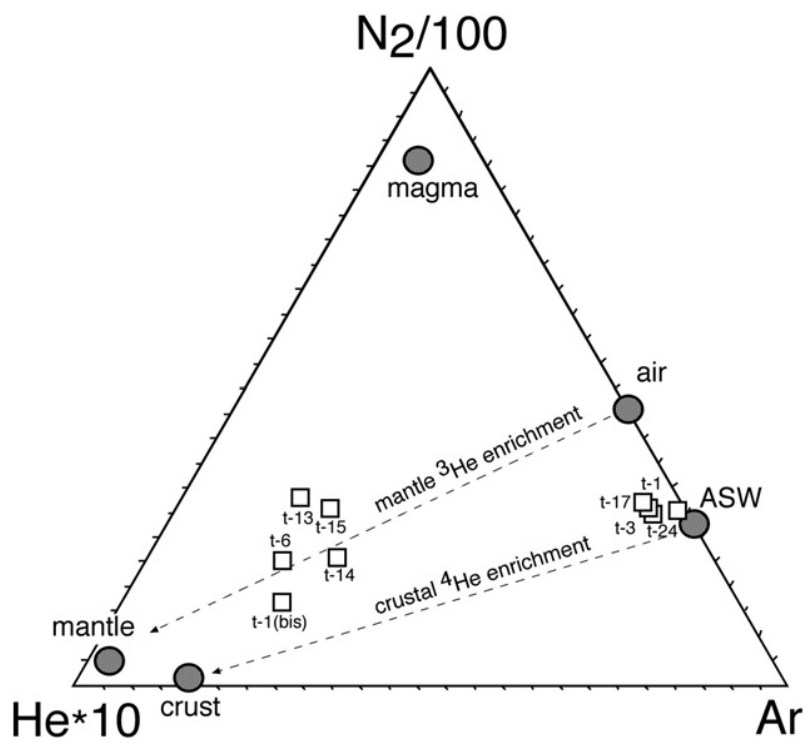

Fig. 8. Ternary Ar-N2/100-10*He diagram (Giggenbach et al., 1983) with reference positions of air, air-saturated water (ASW), magma and crust.

active and has not been observed since being submerged by the lake and/or lacustrine swamps between 2000 and 2002, as compared to all the other springs in the study area, it showed the following peculiar features:

1) higher temperature $\left(95-96^{\circ} \mathrm{C}\right)$;

2) higher $\mathrm{pH}(9.6)$;

3) higher chloride, fluoride, silica and boron concentrations (Table 1);

4) a marked $+1.5-2.0 \%{ }^{18} \mathrm{O}$-shift, with respect to the Global Meteoric and/or the local Addis Ababa (Ethiopia) meteoric lines (Fig. 5).

This spring was described by Craig et al. (1977) as: “... very high discharging spring emerging 2 meters above the lake level, below a vigorous steam vent located up the cliff...", the vigorous steam vent likely being the Abaya \#7 sample of 1973 (i.e.: the \#et-73, \#eth-13, \#t-14 in Table 1). This spring, although no longer available for sampling, is very important in the geothermal context of the area because it was considered as "... the only evidence for high-temperature subsurface water-rock interaction in the area" (Craig et al., 1977; Ayele et al., 2002; Chernet, 2011).

According to the dominantly $\mathrm{Na}-\mathrm{HCO}_{3}$ composition of all thermal (and non-thermal) springs in the Abaya area, it is evident that there is only one main dominant water-interaction process, triggered by $\mathrm{CO}_{2}$ likely related to a mantle source, as suggested by the isotopic composition of carbon isotopes. No limestone or evaporitic rocks seem to be involved in the underground circulation, apart from the Abaya \#6 that will be discussed further on.

Regarding the origin of the spring waters, apart from sample Abaya \#6, it is noteworthy that most of them have undergone little changes in chemical composition in time since 1972 (Table 1). Furthermore, the $\delta^{18} \mathrm{O}-\delta \mathrm{D}$ diagram (Fig. 5) suggests that most of the thermal springs lie in a quite narrow range of meteoric values between the Global and the Addis Ababa meteoric lines. Fig. 5 also suggests that the isotopic composition of rainfalls in Addis Ababa is extremely variable according to the direction of perturbations and monsoons (Levin et al., 2009) and that the event sampled at Soddo Town in 1976 b (Craig et al., 1977) is significantly depleted in ${ }^{18} \mathrm{O}$ of water with respect to thermal springs, being sampled at about $2000 \mathrm{~m}$ elevation. Moreover, the local cold springs are isotopically heavier than most thermal springs. As expected, some rivers and the Abaya Lake are strongly affected by evaporation and lie along an evaporation line whose equation is $\delta \mathrm{D}=5.5 \delta^{18} \mathrm{O}+8.5$.
As previously mentioned, the Abaya sample \#6 has an oxygen-18 shift reported as due to high temperature $\left(>150^{\circ} \mathrm{C}\right)$ water-rock interaction processes (Craig et al., 1977). Similarly, the Abaya \#7 steam condensate can be regarded as being derived from a high-temperature evaporating aquifer as suggested by Craig et al. (1977). Nevertheless, the main questions are how fluids from a deep hydrothermal system can discharge at the surface, after crossing a shallower, likely colder aquifer, such as the one represented by the many thermal samples of Chewkare and North Abaya, and yet maintain a higher temperature and a different chloride concentration? Moreover, it is unclear how this hot, deep, high $\mathrm{pH}$ and low- $\mathrm{CO}_{2}$ fluid can be so spatially diverse (Table 3), but exhibit isotopic ${ }^{13} \mathrm{C} /{ }^{12} \mathrm{C}$ ratios consistent with a mantle origin?

In an attempt to address these intriguing questions, the outlet temperatures are plotted versus the estimated $\mathrm{PcO}_{2}$ values (calculated by PHREEQC geochemical code) in Fig. 9. The figure shows that the highest $\mathrm{PCO}_{2}$ values, as it would be expected, are not coinciding with the highest temperature springs, i.e., Abaya \#6. In particular, they are constrained within a narrow area coinciding with the thermal springs emerging just north of the Abaya \#6 area, along the main fault bordering the western edge of the Chewkare graben. This is only partly in agreement with the magnetotelluric sounding measurements conducted near the North Abaya thermal springs (Desissa and Lema, 2006), which suggests that this area is likely the main upflow zone along which the hydrothermal fluids migrate to the surface. The low resistivity values from the surface up to $1500 / 2000 \mathrm{~m}$ point to a shallow convective system for fluids rapidly rising up through different fractures in a complex high permeability dynamic context where $\mathrm{CO}_{2}$-rich and $\mathrm{N}_{2}$-rich (Abaya \#6) fluids are present in short distances. All the other thermal springs in the area (e.g., Bolocho and the cluster of thermal springs that emerge in the Bilate-Tobacco area along the Bilate River; Fig. 2) have lower $\mathrm{PcO}_{2}$ even though they exhibit a higher temperature than the Chewkare and north Abaya samples.

Another important clue about the origin and interaction of these gases is displayed by the position of Abaya \#7 (et-73) and Abaya \#6 in Fig. 5. The latter, described as a "frying pan" pool at $90.8^{\circ} \mathrm{C}$, lies on the evaporation line, the isotopically lighter end-member being represented

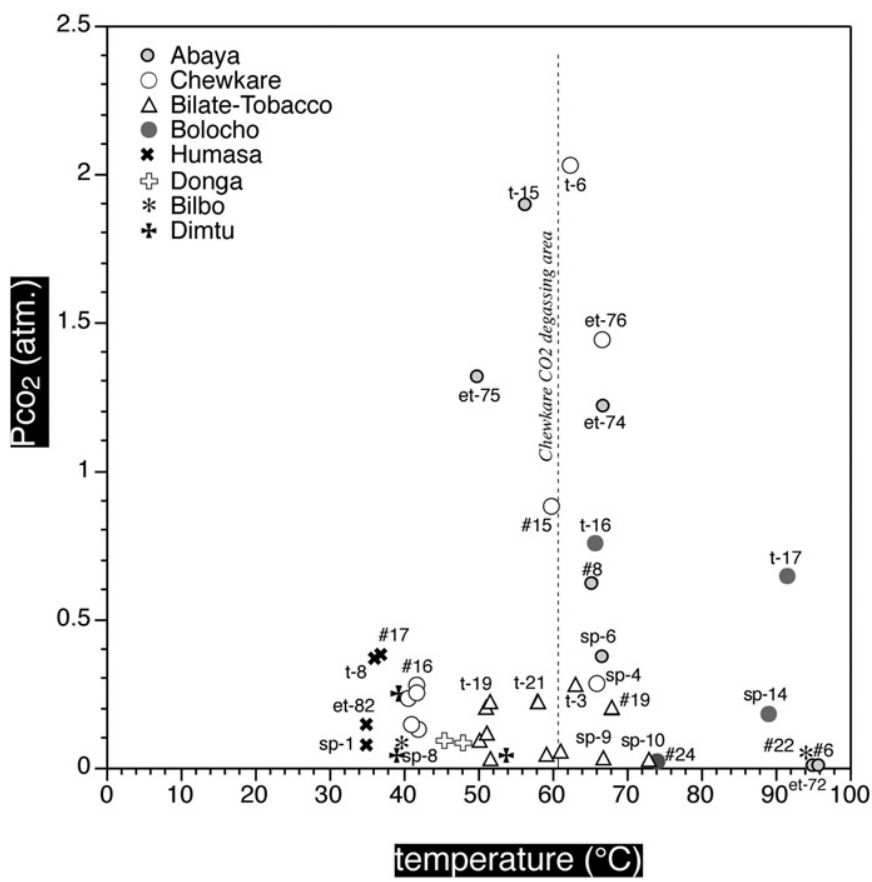

Fig. 9. Binary diagram of calculated $\mathrm{PcO}_{2}$ (Parkhurst and Appelo, 1999) vs. the emergence temperature of thermal springs. The figure clearly suggests anomalous $\mathrm{CO}_{2}$ degassing along the Chewkare area (see text). 
by Abaya \#6 whose geographical position was near Abaya \#7. These observations may allow us to hypothesize that Abaya \#7 could have been an evaporated steam condensate of the steam of sample \#6 that reaches the surface at higher elevation along a different path.

A similar complex area of thermal fluid surface manifestations is present at Bolocho. Here, as described in 1972 , a spring at $74{ }^{\circ} \mathrm{C}$ was discharging a relevant flow rate (75 L/s: sample \#24, U.N.D.P., 1973). This site was not described by the 2nd UN mission in 1976, while in 2000 it was sampled by Ayele et al. (2002), who recorded a temperature of $89{ }^{\circ} \mathrm{C}$. In the same area, during our 2015 mission, two low flow rate $(<3 \mathrm{~L} / \mathrm{min}$ ) thermal pools (\#t-16 and \#t-17 in Table 1) discharging at temperature of 65.8 and $91.5^{\circ} \mathrm{C}$, respectively, with a $\mathrm{CO}_{2}$-rich associated gas-phase were found. The TDS value of the hottest spring here was $>4000 \mathrm{mg} / \mathrm{L}$, i.e., similar to the Abaya \#6 sample, although with a much lower content of chloride. In the $\delta^{18} \mathrm{O}-\delta \mathrm{D}$ diagram of Fig. 5 , the three samples from Bolocho show an ${ }^{18} \mathrm{O}$-shift similar to that of Abaya \#6, although their alignment can also be interpreted as the result of an evaporation process. In spite of some similarities between the Abaya \#6 and the Bolocho samples, the aquifers feeding the two systems are likely different.

The two thermal spring systems of Donga, east of Lake Abaya and Hamesa spring field, west of Lake Abaya, have much lower temperature emissions. Isotopically, they are similar to the north Abaya, Chawkhare and Bilate-Tabacco springs (Fig. 5), suggesting similar meteoric recharge areas (or elevations). The neutral-to-slightly alkaline $\mathrm{pH}$ values and absence of a $\mathrm{CO}_{2}$-rich associated gas-phase likely point to a marginal position of these systems with respect to the main thermal area that seems to be centred on Bolocho and Bilbo fumaroles.

\subsection{Thermal interpretation of manifestations and geothermometry}

The presence of steam vents and fumaroles and/or stagnant acidic frying pools made of steam condensates at boiling and/or near-boiling conditions at outlet elevations, with or without a relevant associated $\mathrm{CO}_{2}$ gas phase, is obviously a good indication of high thermal gradients at shallow depths. If these emissions are associated with the presence of active or recent volcanism of acidic composition, such as that in the Abaya area (rhyolithic), one might expect that the geothermal potential is likely high (shallow differentiated magma chambers).

Conversely, alkaline springs, with high flow rate, and a $\mathrm{N}_{2}$-rich associated gas phase, even at near boiling conditions, such as the Abaya \#6 spring, may not necessarily be related exclusively to anomalous thermal areas, but may also relate to long convective, circulating groundwater. Nevertheless, in geothermal areas these two types of emissions can coexist, as documented in the Italian Larderello geothermal field (Minissale, 1991) or central Madagascar (Minissale et al., 1999). Alkaline thermal springs rich with an $\mathrm{N}_{2}$-gas phase, such as those discharging north of Lake Abaya, can indeed represent marginal aquifers conductively heated, in areas where the thermal gradient is high, and where the relative aquifers may interfere with each other, or may not if sealing processes are active.

Craig et al. (1977), Ayele et al. (2002) and Chernet (2011) considered the Abaya \#6 sample as the best manifestation of the area in terms of geothermal significance, mostly because of the $1.5-2.0 \%$ shift in $\delta^{18} \mathrm{O}$ of water (Fig. 5). Presently, this remains the only spring that shows an isotopic shift and according to the previous interpretation. This observation would mean that all other northern thermal springs, and steam vents, are more "shallow" marginal manifestations of the main thermal system, as opposed to unique high thermal anomaly areas, that might be located somewhere underground in the southern part of the study area, possibly even under the Abaya Lake. However, the question about the high $\mathrm{pH}$ waters remains open since it appears unlikely that a hydrothermal system may generate fluid with a $\mathrm{pH}>9$. Instead, a much more probable explanation for the oxygen and $\mathrm{pH}$ shift is a long residence time of this thermal groundwater, specifically in a large convective system at boiling or near boiling conditions, in a convective marginal aquifer with respect to the main geothermal area, likely located northward. If the residence time of these convecting fluids is sufficiently long enough, a $2-3 \%{ }^{18} \mathrm{O}$-shift does not require boiling temperatures, but can occur over time in unconfined aquifers with conductivity to the surface aquifers, as was documented previously e.g., in the low-enthalpy Tianjin geothermal system in China (Minissale et al., 2008).

To test this hypothesis, we examine further evidence for extended residence time of the ground water discharged by the Abaya sample \#6. The high chloride (and fluoride) content could indicate long residence time, especially in a geological context such as this where extensive interactions with evaporites or marine formations are unlikely (none known in this area). Thus, we hypothesize that these chloride levels are derived from either the alteration of volcanic or sedimentary alluvial material, which have relatively low concentrations of these components, and thus require extensive time for water-rock interactions. Another possibility is that the elevated $[\mathrm{Cl}]$ could result from the condensation of volcanic $\mathrm{HCl}$, which could be possible in this area. Nonetheless, the volcanic $\mathrm{HCl}$ would likely be associated with an elevated flux of $\mathrm{CO}_{2}$-rich fluids. Thus, we do not consider a large flux of volcanic gases as a viable source in light of the high $\mathrm{pH}$ values that are identified in this spring. Although more data is needed to reach a definitive conclusion, we suggest that long residence times represent a viable mechanism for elevated $[\mathrm{Cl}]$.

Once the Abaya \#6 sample is excluded from consideration, we evaluate the thermal conditions using geothermometry methods related to spring compositions following the Giggenbach $(1986,1988)$ method. This commonly used method is based on a $\mathrm{Na}(/ 1000)-\mathrm{K}(/ 100)-\mathrm{Mg}^{\wedge 0.5}$ triangular diagram based on two geothermometers, including the typical K/Na geothermometer in the Giggenbach formulation (Giggenbach et al., 1983) and the $\log \left(\mathrm{K}^{2} / \mathrm{Mg}\right)$ geothermometer proposed by Giggenbach in 1991 (Giggenbach, 1991).

This Giggenbach method, shown graphically in Fig. 10, assumes an average crustal composition that, when altered to produce sericite and chlorite in a hydrothermal system that is saturated in quartz, produces dominantly common silicates, and results in the concentration of $\mathrm{K}$, $\mathrm{Na}$ and $\mathrm{Mg}$ being fixed by the temperature of the system (shown as the full equilibrium line line in Fig. 10). The diagram also defines an area of mixing (or dilution) with shallow solutions typically enriched

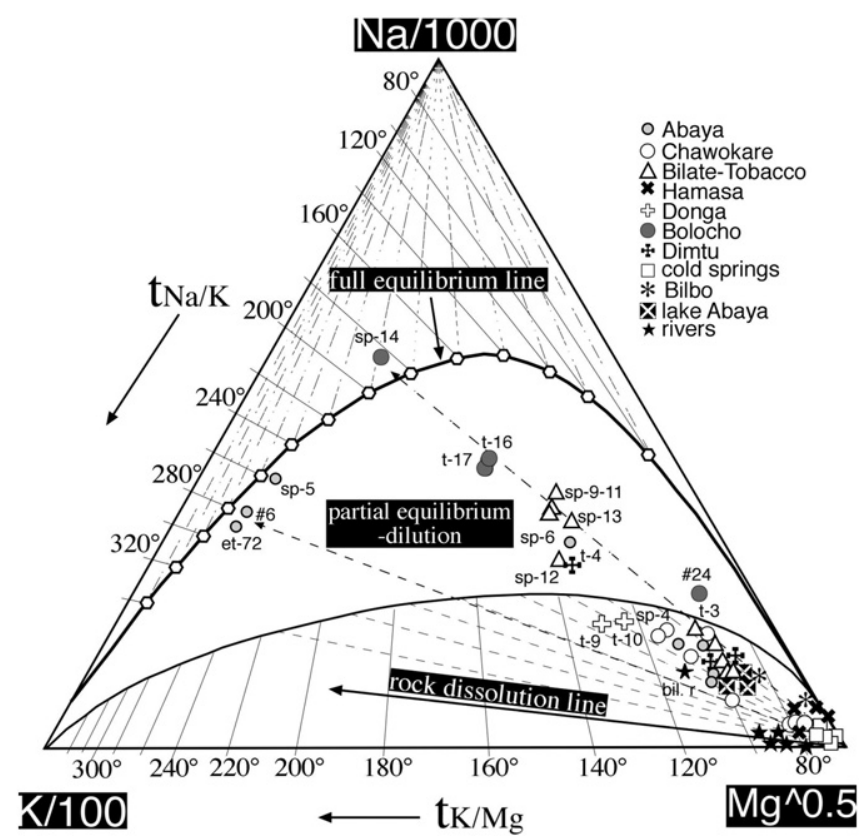

Fig. 10. Geothermometric ternary Na/1000-K/100-Mg^0.5 diagram (Giggenbach, 1986, 1988 ) showing a dilution/mixing line of thermal springs with fluids equilibrated in a potential reservoir at about $180{ }^{\circ} \mathrm{C}$ (see text). 
in $\mathrm{Mg}$, and a line of dissolution of silicates at low temperature at a constant $\mathrm{Na} / \mathrm{K}$ ratio when alkali elements increase with time of dissolution (Giggenbach, 1988). When applied to well-known geothermal areas, such as the Mt. Amiata area in Tuscany (Italy), only fluids discharging from deep geothermal wells align along the full equilibrium line, but mixing line(s) from deep wells and shallow springs in the so called mixing area, are commonly recognised (Minissale et al., 1997). Fig. 10 shows the diagram applied to the Abaya area where it is clear that all samples are not aligned along the equilibrium line. All cold samples and river waters are near the $\mathrm{Mg}$ corner, as expected; all the thermal springs fall along a straight line towards equilibration temperatures of about $180^{\circ} \mathrm{C}$ for both the $\mathrm{Na} / \mathrm{K}$ and the $\mathrm{K} / \mathrm{Mg}$ geothermometers (sample \#sp-14). The Abaya sample \#6 (et-72; sp-5) is apparently located along the equilibrium line at temperature about $280^{\circ} \mathrm{C}$, but this position is misleading because of the fact that the water is deprived of $\mathrm{Ca}$ and $\mathrm{Mg}$ because of saturation with several $\mathrm{Ca}$ and $\mathrm{Mg}$ minerals including: calcite, dolomite, magnesite, talc, sepiolite, etc. (Table 3); therefore the $\mathrm{K} / \mathrm{Mg}$ ratio is unrealistic being the position of the spring in the diagram artificially shifted towards the K-Na side.

All the other thermal samples are aligned at a constant $\mathrm{Na} / \mathrm{K}$ ratio, which likely suggests that they share a common parent aquifer, depleted in Mg. As for the Abaya \#6 sample, almost all samples are saturated in magnesite and the highest temperature springs at Bolocho, Bilbo and Bilate-Tobacco plantation are also saturated in talc and sepiolite (Table 3). We suggest that the deep equilibration temperature of $180{ }^{\circ} \mathrm{C}$ is probably realistic, with respect to the $260{ }^{\circ} \mathrm{C}$ suggested by the Abaya \#6 sample, because the temperature estimates are confirmed by the gas phase geothermometers (discussed further below); additional evidence that confirms this interpretation stems from the fact that none of these thermal springs display a marked oxygen-18 shift in water, contrary to the Abaya \#6 sample.

An alternative way to evaluate the history of water-rock interactions and perform geothermometry in liquid phase can be achieved by comparing the $\log (\mathrm{Na} / \mathrm{K})$-T diagram of Fig. 4 (bottom right). This diagram shows that the $\mathrm{Na} / \mathrm{K}$ ratio of most springs is not constrained by the equilibrium between the albite/K-feldspar pair, as is the case in most high temperature hydrothermal systems. Instead, these data are consistent with the dilution of waters with the Na-montmorillonite/K-montmorillonite pair by colder, shallow flowing fluids. If we imagine a dilution with deep fluids, by extending the albite/K-feldspar theoretical equilibrium line, a similar temperature of $180^{\circ} \mathrm{C}$ estimated with the Giggenbach triangular diagram, can be achieved for the Bolocho samples, which represent the least diluted samples in the area.

As mentioned, a similar estimate of deep equilibration temperatures can be achieved using the gas composition in the few places where samples with minimal air contamination were obtained, i.e., at Chawokare. Among the many possibilities given by gas components, we have considered here the relations among the measured species: $\mathrm{H}_{2} \mathrm{O}, \mathrm{CO}_{2}, \mathrm{H}_{2}$, $\mathrm{CO}$ and $\mathrm{CH}_{4}$ in those samples in which these elements have been determined. As described by the following chemical reactions:

$\mathrm{CO}_{2}+\mathrm{H}_{2} \Leftrightarrow \mathrm{CO}+\mathrm{H}_{2} \mathrm{O}$

$3 \mathrm{CO}_{2}+\mathrm{CH}_{4} \Leftrightarrow 4 \mathrm{CO}+2 \mathrm{H}_{2} \mathrm{O}$

whose temperature dependence (Chiodini and Marini, 1998) is given by the relations:

$\log \left(\mathrm{X}_{\mathrm{CO}} / \mathrm{X}_{\mathrm{CO} 2}\right)-\log \left(\mathrm{X}_{\mathrm{H} 2} / \mathrm{X}_{\mathrm{H} 2 \mathrm{O}}\right)=-2248 / \mathrm{T}+2.485$

$3 \log \left(\mathrm{X}_{\mathrm{CO}} / \mathrm{X}_{\mathrm{CO} 2}\right)+\log \left(\mathrm{X}_{\mathrm{CO}} / \mathrm{X}_{\mathrm{CH} 4}\right)=-17,813 / \mathrm{T}+19.605$

The deep equilibration temperatures can be estimated using the molar fraction $\mathrm{X}$ of single species. The dependence of the $[\log (\mathrm{CO} /$ $\left.\left.\mathrm{CO}_{2}\right)-\log \left(\mathrm{H}_{2} / \mathrm{H}_{2} \mathrm{O}\right)\right]$ and $\left[3 \log \left(\mathrm{CO} / \mathrm{CO}_{2}\right)+\log \left(\mathrm{CO} / \mathrm{CH}_{4}\right)\right]$ in: i) a single saturated vapour phase (vapour), ii) single saturated liquid phase (liquid) and iii) liquid + vapour produced by single-step vapour separation (SSVS) at temperatures ranging from 150 to $350^{\circ} \mathrm{C}$, are graphically described in Fig. 11. The main advantage of this approach is that the two sums of log-ratios only depend on temperature and water fugacity, and are not controlled by any redox pair. According to this geothermometric approach, the fumarolic gases from North Abaya and Boramitta seem to have attained equilibrium at about $150-200{ }^{\circ} \mathrm{C}$. Noteworthy, the North Abaya samples \#t-13 and \#t-14 plot out of the vapour-liquid grid, likely due to steam condensation of about $50 \%$ of the original steam, as suggested by the relatively low outlet temperature of these fumaroles.

In conclusion, the area north of Lake Abaya seems to be a large geothermal area that should have a deep reservoir discharging fluids at about $180^{\circ} \mathrm{C}$. However, it is important to note that this system is largely diluted by shallow colder components not able to completely reequilibrate single components both in the liquid and the gas phase.

\subsection{Lake Abaya}

Lake Abaya is one of the several lakes located along the Ethiopian rift system (Chernet, 1982; Darling et al., 1996; Ayenew, 2009). Like other lakes along the rift, Abaya has suffered dramatic lake level changes in recent decades (e.g., Ayenew and Becht, 2008; Alemayehu et al., 2006) either resulting from oscillations or long terms variations (Belete et al., 2016). Such water level oscillations have mostly been related to climate changes and/or changing in the hydrology of rivers feeding the system, although no changes in the chemistry were described previously.

In Table 1, the chemical compositions of Abaya Lake measured in 1972, 1977, 2000 and 2015 are listed. The major composition $\left(\mathrm{Na}-\mathrm{HCO}_{3}\right.$ ) has not changed throughout time (Fig. 3). However, some variations were recorded, as follows: i) TDS steadily increased from $754 \mathrm{mg} / \mathrm{L}$ in 1977 to $849 \mathrm{mg} / \mathrm{L}$ in 2015, ii) pH decreases from 8.85 to 8.53 , and iii) the $\delta \mathrm{D}$ and $\delta^{18} \mathrm{O}$ values dropped from +49.6 to $+40.2 \%$ and from 7.25 to $5.69 \%$, respectively (Fig. 12). From 1980 to 1998 the water level increased by about $3 \mathrm{~m}$ and then subsequently decreased by approximately $3 \mathrm{~m}$ from 1988 to 2006 (Belete et al., 2016). The highest stand in 1998 was coincident with the submersion of the

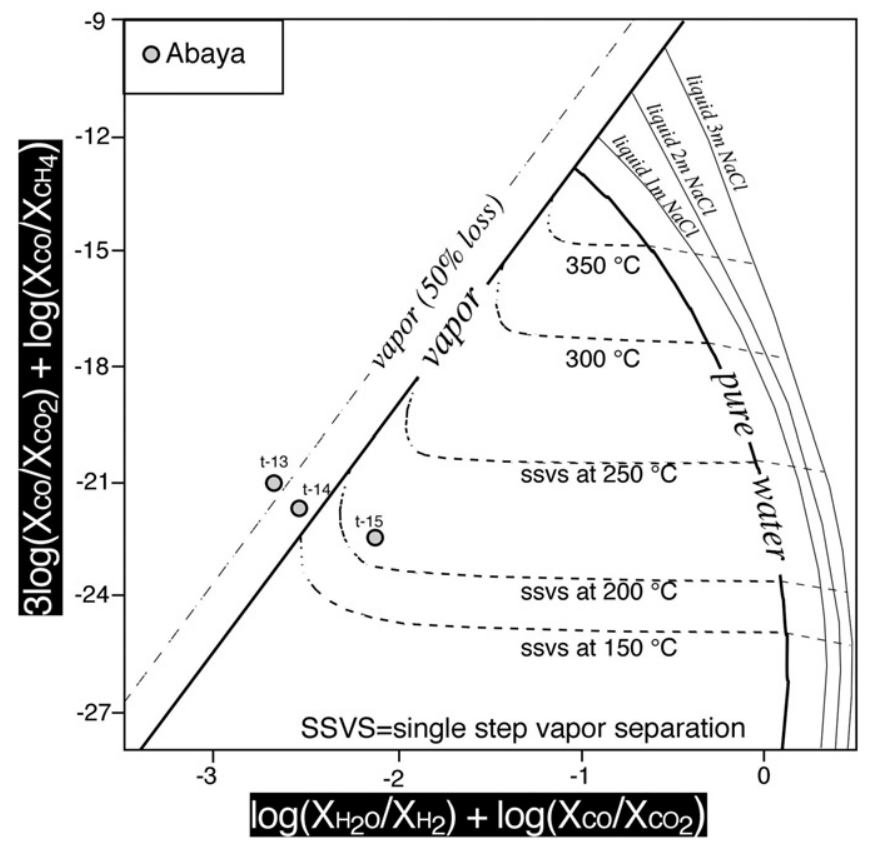

Fig. 11. Gas ratio diagram (Chiodini and Marini, 1998) of $\log \left(\mathrm{X}_{\mathrm{H} 2 \mathrm{O}} / \mathrm{X}_{\mathrm{H} 2}\right)+\log \left(\mathrm{X}_{\mathrm{CO}} / \mathrm{X}_{\mathrm{CO} 2}\right)$ vs. $3 \log \left(\mathrm{X}_{\mathrm{CO}} / \mathrm{X}_{\mathrm{CO} 2}\right)+\log \left(\mathrm{X}_{\mathrm{CO}} / \mathrm{X}_{\mathrm{CH} 4}\right)$. The theoretical values of both variables in a single saturated vapour phase and in a single saturated liquid phase, for $\mathrm{NaCl}$ concentrations of $0,1,2$, and $3 \mathrm{M}$ are shown, together with the analytical gas ratios for the gas samples investigated. 


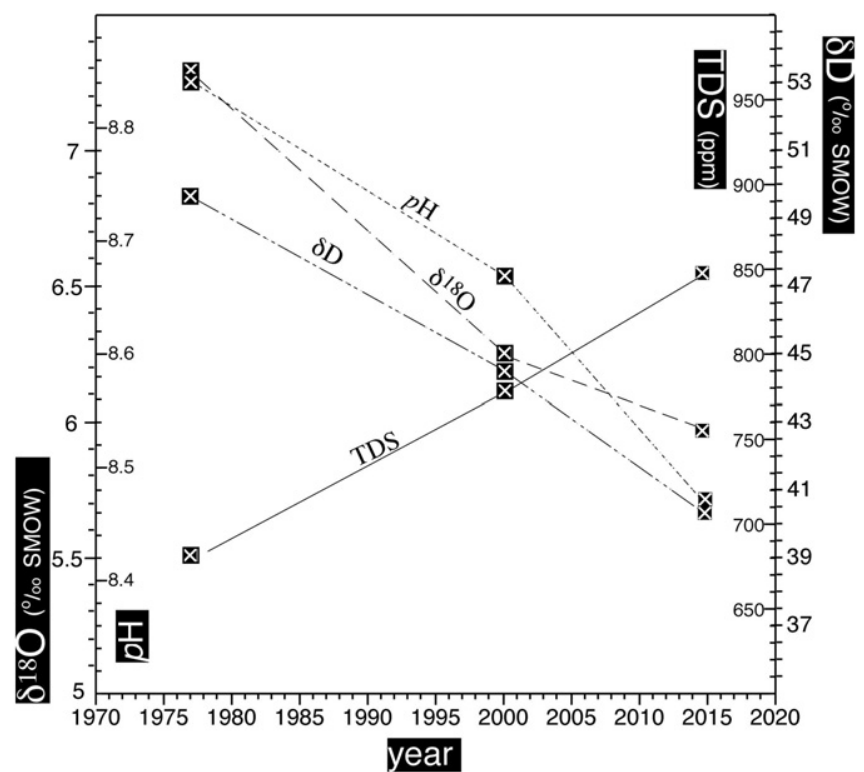

Fig. 12. In time-variation diagram of: $\delta^{18} \mathrm{O}, \mathrm{pH}$, salinity (TDS) and $\delta \mathrm{D}$, for the water of the Lake Abaya. The diagram shows, from 1976 to 2015, a marked increase in salinity and contemporary decrease in $\mathrm{pH}, \delta^{18} \mathrm{O}$ and $\delta \mathrm{D}$ (see text).

Abaya \#6 sampled in 2000, as reported by Ayele et al. (2002). It is difficult to understand the reason why the presence of thermal springs did not recover afterwards, although no data on the water lake level after 2006 are available, and the water level may have increased again since then, as suggested by preliminary analysis of satellite images (Google Earth Imagery). By comparison, there is a marked increase in TDS during this time period, which suggests either more efficient evaporation during the last 40 years or a change in the TDS load of water inputs. While evaporation could increase in response to climate change throughout the last 20 years, this hypothesis is not compatible with the significant decrease of the $\delta \mathrm{D}$ and $\delta^{18} \mathrm{O}$. If we couple this isotopic decrease with the coincident decrease in $\mathrm{pH}$ (from 8.85 to 8.42 ), we can speculate that these changes in water chemistry instead relate to differing chemistry of water inputs. For example, the lake could be affected changing stream chemistry or sub-lacustrine water contributions, such as subaqueous magmatic gas emanations that could be isotopically lighter and $\mathrm{CO}_{2}$-rich.

These contributions cannot be related to the groundwater chemistry in the aquifer supplying the submerged Abaya \#6 sample since it was characterized by a $\mathrm{pH}=9.5$, that should eventually cause a $\mathrm{pH}$ increase of the lake water. Since the lake temperatures were likely measured at the surface of the lake, the thermal character of such deep contributions cannot be evaluated. Nevertheless, the measured temperature of the lake was $26{ }^{\circ} \mathrm{C}$ in $1972,28{ }^{\circ} \mathrm{C}$ in April 2000 and $29.4{ }^{\circ} \mathrm{C}$ in October 2015 , suggesting therefore an approximate increase of $0.08^{\circ} \mathrm{C} / \mathrm{y}$ since 1972.

\section{Conclusions}

As many other areas located along the Ethiopian sector of the African Rift Valley, the region located north of the Abaya Lake can be regarded as a very promising geothermal areas since it is characterized by: i) very active tectonics, ii) young volcanism of rhyolitic signature likely suggesting magma differentiation at shallow depth, iii) boiling steam emissions and thermal springs, and iv) elevated estimated deep temperatures. The isotopic composition of $\delta^{13} \mathrm{C}-\mathrm{CO}_{2},{ }^{3} \mathrm{He} /{ }^{4} \mathrm{He}$, and $\mathrm{CO}_{2} /{ }^{3} \mathrm{He}$ ratios clearly suggests the presence of an active degassing mantle, similarly to other geothermal fields in the EARS (e.g., Darling et al., 1995; Barry et al., 2013; Darrah et al., 2013).
The potential area that deserves further exploration is $>500 \mathrm{~km}^{2}$ : from the northern lakeshore area to the Doguna volcano (Dimtu). The location of the thermal emissions does not provide any indication of where the best geothermal area is located at depth. In fact, thermal springs often are marginal emissions of diluted deep fluids, eventually emerging in low topographic areas and/or along faults bordering active volcanoes, of hydrothermal systems located at higher elevation (a review in Ingebritsen et al., 2006).

Under this perspective the study area is not an exception; most of the thermal springs discharge in low topographic areas along the Bilate River, whose SSW flow is constrained by the fault system bordering the rift (Corti et al., 2013). As described in the previous sections, apart from a restricted area at the western edge of the Chewkare graben (Fig. 2), the emission of $\mathrm{CO}_{2}$ is generally low. This low $\mathrm{CO}_{2}$ emission is not necessarily a bad situation from a thermal point of view, since it could be related to two reasons: i) because the carbon concentration in the local mantle is low (degassed), and ii) because any deep hydrothermal system is likely located in crystalline rocks where presence of carbonate material is unlikely. The isotopic signature of carbon in $\mathrm{CO}_{2}$ has a mantle signature and $\mathrm{CO}_{2}$ concentration in the mantle is generally very low.

According to the triangular Na-K-Mg diagram (Fig. 10), the most significant springs seem to be those emerging at Bolocho, which coincide with the central part of the whole thermal area, between the recent volcanism associated with the Doguna and the Salewa-Dore volcanoes. These two volcanic areas are to be considered the main areas to attempt a preliminary drilling activity at shallow depth. However, even the large areas between these two volcanoes, with the dozens of small scoria cones deserve some attention. They may be the expression of a deep basaltic volcanism fed through the many active fault systems, although they might also be formed from shallow magma chamber(s) not revealed by the geophysical investigations performed so far.

The few magnetotelluric profiles described in Desissa and Lema (2006) seem to definitely be insufficient to understand the thermal regime, deep fluid motion of the region and geothermal potential, which still remains not well assessed, but definitely very high.

\section{Acknowledgements}

Many thanks are due to Enrico Calvi (CNR-IGG) for performing $\delta^{13} \mathrm{C}$ $\mathrm{CO}_{2}$ analyses. Special thanks to the driver Aron Fesseha who accompanied GC, DM and OV during the 2015 fieldtrip.

\section{References}

Alemayehu, T., Ayenew, T., Kebede, S., 2006. Hydrogeochemical and lake level changes in the Ethiopian Rift. J. Hydrol. 316, 290-300.

Arnòrsson, S., 1985. The use of mixing models and chemical geothermometers for estimating underground temperatures in geothermal systems. J. Volcanol. Geotherm. Res. 23, 299-335.

Ayele, A., Teklemariam, M., Kebede, S., 2002. Resources Exploration in the Abaya and Tulu Moye-Gademsa Geothermal Prospects, Main Ethiopian Rift. Report of the Geological Survey of Ethiopia, Addis Ababa, Ethiopia (69pp.).

Ayenew, A., 2009. Natural Lakes of Ethiopia. Addis Ababa University Press, Addis Ababa, Ethiopia (256pp.)

Ayenew, T., Becht, R., 2008. Comparative assessment of the water balance and hydrology of selected Ethiopian and Kenyan Rift lakes. Lakes Reserv. Res. Manag. 13, 181-196.

Ayenew, T., Egziabher, G.M., 2015. Morphometric characteristics and hydrology of selected Ethiopian Rift lakes. In: Billi, P. (Ed.), Landscapes and Landforms of Ethiopia. World Geomorphological Landscapes. http://dx.doi.org/10.1007/978-94-017-8026-1_16.

Ballentine, C.J., Burgess, R., Marty, B., 2002. Tracing fluid origin, transport andinteraction in the crust. In: Porcelli, D., Ballentine, C.J., Wieler, R. (Eds.), Noble Gases in Geochemistry and Cosmochemistry, pp. 539-614.

Barry, P.H., Hilton, D.R., Fischer, T.P., de Moor, J.M., Mangasini, F., Ramirez, C., 2013. Helium and carbon isotope systematic of cold "mazuku" C $=2$ vents and hydrothermal gases and fluids from Rungwe Volcanic Province, southern Tanzania. J. Volcanol. Geotherm. Res. 339, 141-156.

Belete, M.D., Diekkruger, B., Roehring, J., 2016. Characterization of water level variability of the Main Ethiopian Rift Valley Lakes. Hydrology 3. http://dx.doi.org/10.3390/ hydrology3010001

Bencini, A., 1985. Applicabilità del metodo dell'Azometina-H alla determinazione del boro nelle acque naturali. Rend. Soc. Ital. Mineral. Petrol. 40, 311-316. 
Biggs, J., Bastow, I.D., Keir, D., Lewi, E., 2011. Pulses of deformation reveal frequently recurring shallow magmatic activity beneath the Main Ethiopian Rift. Geochem. Geophys. Geosyst. 12:9. http://dx.doi.org/10.1029/2011GC003662.

Chernet, T., 1982. Hydrogeology of the Lakes Region, Ethiopia. Ministry of Mines and Energy Report, Addis Ababa, Ethiopia (97pp.).

Chernet, T., 2011. Geology and hydrothermal resources in the northern Lake Abaya area (Ethiopia). J. Afr. Earth Sci. 61, 129-141.

Chiodini, G., Marini, L., 1998. Hydrothermal gas equilibria: the $\mathrm{H}_{2} \mathrm{O}-\mathrm{H}_{2}-\mathrm{CO}_{2}-\mathrm{CO}-\mathrm{CH}_{4}$ system. Geochim. Cosmochim. Acta 62, 2673-2687.

Coleman, M.L., Shepherd, T.J., Durham, J.J., Rouse, J.E., Moore, G.R., 1982. Reduction of water with zinc for hydrogen isotope analysis. Anal. Chem. 54, 993-995.

Corti, G., Sani, F., Philippon, M., Sokoutis, D., Willingshofer, E., Molin, P., 2013. Quaternary volcano-tectonic activity in the Soddo region, western margin of the Southern Main Ethiopian Rift. Tectonics 32, 861-879.

Craig, H., 1961. Isotopic variations in meteoric waters. Science 133, 1702-1703.

Craig, H., et al., 1977. Isotopic Geochemistry and Hydrology of Geothermal Waters in the Ethiopian Rift Valley. Isotope Lab., Scripps Institution of Oceanography, Univ. of California at San Diego, USA, Report S10-77-14 (140pp).

Craig, H., Lupton, J.E., Horibe, Y., 1978. A mantle helium component in circum-Pacific volcanic gases: Hakone, the Marianas, and Mt. Lassen. In: Alexander, E.C., Ozima, M. (Eds.), Terrestrial Rare GasesAdvances in Earth and Planetary Sciences 3. Japan Sci. Soc, Tokyo, pp. 3-16 (1978).

Darling, G.W., 1990. Rift Valley Gas Geothermometry Project. British Geol. Survey, Technical report WD/91/2R, Keyworth, UK (9pp).

Darling, G.W., Greisshaber, E., Andrews, J.N., Armannsson, H., O'Nions, R.K., 1995. The origin of hydrothermal and other gases in the Kenya Rift Valley. Geochim. Cosmochim. Acta 59, 2501-2512.

Darling, G.W., Gizaw, B., Arusei, M.K., 1996. Lake-groundwater relationship and fluid-rock interaction in the East African Rift Valley: isotopic evidence. J. Afr. Earth Sci. 22, 423-431.

Darrah, T.H., Poreda, R.J., 2012. Evaluating the accretion of meteoritic debris and interplanetary dust particles in the GPC-3 sediment core using noble gas and mineralogical tracers. Geochim. Cosmochim. Acta 84, 329-352.

Darrah, T.H., Tedesco, D., Tassi, F., Vaselli, O., Cuoco, E., Poreda, R.J., 2013. Gas chemistry of the Dallol region of the Danakil Depression in the Afar region of the northern-most East African Rift. Chem. Geol. 339, 16-29.

Deines, P., 2002. The carbon isotope geochemistry of mantle xenoliths. Earth Sci. Rev. 58, 247-278.

De la Torre, I., Benito-Calvo, A., Mora, R., Martinez-Moreno, J., Moran, N., Tibebu, D., 2007. Stone Age occurrences in the western bank of the Bilate River (Southern Ethiopia)some preliminary results. Nyame Akuma 67, 14-25.

Desissa, M., Lema, Y., 2006. The Resistivity Structure of the Abaya Geothermal Field, (Southern Main Ethiopian Rift) Revealed by Magneto-telluric Imaging. Geological Survey of Ethiopia report, Addis Ababa, Ethiopia (23pp).

Didana, Y.L., Thiel, S., Heinson, G., 2015. Three dimensional conductively model of the Tendaho geothermal field, NE Ethiopia. J. Volcanol. Geotherm. Res. 290, 53-62.

Epstein, S., Mayeda, T.K., 1953. Variation of oxygen-18 content of waters from natural sources. Geochim. Cosmochim. Acta 4, 213-224.

Evans, W.C., White, L.D., Rapp, J.B., 1998. Geochemistry of some gases in hydrothermal fluids from the southern San Juan de Fuca ridge. J. Geophys. Res. 15, 305-313.

Facca, G., Tonani, F., 1967. The self-sealing geothermal field. Bull. Volcanol. 30, 271-273.

Fournier, R.O., 1977. Chemical geothermometers and mixing models for geothermal systems. Geothermics 5, 41-50.

Fournier, R.O., 1991. Water geothermometers applied to geothermal energy. In: D'Amore, F. (Ed.), Application of Geochemistry in Geothermal Reservoir Development. UNITAR, Rome, Italy, pp. 37-65.

Giggenbach, W.F., 1986. Graphical Techniques for the Evaluation of Water/Rock Equilibration Conditions by Use of $\mathrm{Na}, \mathrm{K}, \mathrm{Mg}$ and Ca-contents of Discharge Waters. Proc. 8th New Zealand Geothermal Work pp. 37-44.

Giggenbach, W.F., 1988. Geothermal solute equilibria: derivation of Na-K-Mg-Ca geoindicators. Geochim. Cosmochim. Acta 52, 2749-2765.

Giggenbach, W.F., 1991. Chemical techniques in geothermal exploration. In: D'Amore, F. (Ed.), Application of Geochemistry in Geothermal Reservoir Development. UNITAR, Rome, Italy, pp. 119-144.

Giggenbach, W.F., Gonfiantini, R., Jangi, B.L., Truesdell, A.H., 1983. Isotopic and chemical composition of Parbaty Valley geothermal discharges, NW-Himalaya. Geothermics $12,199-222$.

Gizaw, B., 1993. Aluto-Langano geothermal field, Ethiopian Rift valley: physical characteristics and the effects of gas on well performance. Geothermics 22, 101-116.

Gizaw, B., 1996. The origin of high bicarbonate and fluoride concentrations in waters of the Main Ethiopian Rift Valley, East Africa Rift system. J. Afr. Earth Sci. 22, 391-402.

Hunt, A.G., Darrah, T.H., Poreda, R.J., 2012. Determining the source and genetic fingerprint of natural gases using noble gas geochemistry: a northern Appalachian Basin case study. Am. Assoc. Pet. Geol. Bull. 96, 1785-1811.

Ingebritsen, S.E., Sanford, W.E., Neuzil, C.E., 2006. Groundwater Flow in Geologic Processes. second ed. Cambridge Univ. Press, Cambridge, U.K. (536pp).
Kebede, S., 2014. Status of Geothermal Exploration and Development in Ethiopia. Proc. 5th ARGeo-c5 Conference, 29-31 Oct. 2014 (Arusha, Tanzania). (4pp).

Keranen, K., Klemperer, S.L., Gloaguen, R., Eagle working group, 2004. Three-dimensional seismic imaging of a protoridge axis in the Main Ethiopian Rift. Geology 32, 949-952.

Langelier, W., Ludwig, H., 1942. Graphical methods for indicating the mineral character of natural waters. J. Amer. Water Assoc. 34, 335-352.

Lee, H., Muirhead, J.D., Fischer, T.P., Ebinger, C.J., Kattenhorn, S.A., Sharp, Z.D., Kianji, G., 2016. Massive and prolonged deep carbon emissions associated with continental rifting. Nat. Geosci. http://dx.doi.org/10.1038/NGEO2622.

Levin, N.E., Zipser, E.J., Cerling, T.E., 2009. Isotopic composition of waters from Ethiopia and Kenya: insights into moisture sources for eastern Africa. J. Geophys. Res. 114 D23306. http://dx.doi.org/10.1029/2009JD012166.

Mahatsente, R., Jentzsch, G., Jahr, T., 1999. Crustal structure of the Main Ethiopian Rift from gravity data: 3-dimensional modeling. Tectonophysics 313, 363-382.

Mamyrin, B.A., Tolstikhin, I., 1984. Helium Isotopes in Nature. Elsevier, Amsterdam, The Netherland (274pp)

Minissale, A., 1991. The Larderello geothermal field: a review. Earth Sci. Rev. 31, 133-151.

Minissale, A., 2002. Geochemical and geophysical methods in geothermal exploration. In: Chandrasekharam, D., Bundschuh, J. (Eds.), Geothermal Energy Resources for Developing Countries. Balkema Publ, Lisse, The Netherlands, pp. 179-193.

Minissale, A., 2004. Origin, transport and discharge of $\mathrm{CO}_{2}$ in central Italy. Earth Sci. Rev. 66, 89-141.

Minissale, A., Magro, G., Vaselli, O., Verrucchi, C., Perticone, I., 1997. Geochemistry of water and gas discharges from the Mt. Amiata silicic complex and surrounding areas (central Italy). J. Volcanol. Geotherm. Res. 79, 223-251.

Minissale, A., Vaselli, O., Tassi, F., Magro, G., Pezzotta, F., 1999. Thermal Springs Around the Quaternary Volcanic Ankaratra Mts., Madagascar. Proc. 5th GES Intern. Symp., 16-20 Aug pp. 523-526 (Reykiavik, Island).

Minissale, A., Borrini, D., Montegrossi, G., Orlando, A., Tassi, F., Vaselli, O., Delgado, H.A. Yang, J., Cheng, W., Tedesco, D., Poreda, R., 2008. The Tianjin Geotherma Field (north-eastern China): water chemistry and possible reservoir permeability reduction phenomena. Geothermics 37, 400-428.

Mohr, P., Zanettin, B., 1988. The Ethiopian food basalt province. In: Macdougall, J.D. (Ed.), Continental Flood Basalts. Kluwer Academic Publishers, pp. 63-110.

Montegrossi, G., Tassi, F., Vaselli, O., Buccianti, A., Garofalo, K., 2001. Sulphur species in volcanic gases. Anal. Chem. 73, 3709-3715.

Parkhurst, D., Appelo, D.L., 1999. User's Guide to PHREEQC (version 2): A Computer Program for Speciation Batch-reaction, One-dimensional Transport and Inverse Geochemical Calculations. USGS Water-Resources Investigations Report, pp. 99-4259 (309pp).

Philippon, M., Corti, G., Sani, F., Bonini, M., Balestrieri, M.L., Molin, P., Willingshofer, E. Sokoutis, D., Cloetingh, S., 2014. Evolution, distribution and characteristics of rifting in southern Ethiopia. Tectonics 33, 485-508.

Purschel, M., Gloaguen, R., Stadler, S., 2013. Geothermal activities in the Main Ethiopian Rift: hydrogeochemical characterization of geothermal waters and geothermometry applications (Dofan-Fantale, Gerdere-Sodere, Aluto-Langano). Geothermics 47, 1-12.

Rollinson, H., 1993. Using Geochemical Data. Longman Publish, London, U.K. (352pp).

Rooney, T.O., 2010. Geochemical evidence of lithospheric thinning in the southern Main Ethiopian Rift. Lithos 117, 33-48.

Samrock, F., Kuvshinov, A., Bakker, J., Jackson, A., Fisseha, S., 2015. 3-D analysis and interpretation of magnetotelluric data from the Aluto-Langano geothermal field, Ethiopia. Geophys. J. Int. 202, 1923-1948.

Teclu, A., 2003. Geochemical and Isotopic Study of the North Lake Abaya Geotherma Prospect. Proc. Work. Argeo C-4, Entebbe, Uganda (http://theargeo.org/home/files/ Eihiopia/). (5pp).

Teklemarian, M., 2008. Overview of Geothermal Resource Utilization and Potential in the East African Rift System. Proc. Short Course III on Exploration for Geothermal Resources, Organized by UNU-GTP and KenGen, Lake Naivasha, Kenya, Oct. 24-Nov. 17 (9pp).

Teklemarian, M., Kebede, S., 2010. Strategy for Geothermal Resource Exploration and Development in Ethiopia. Proc. 2010 World Geothermal Congress, 25-29 April (Bali, Indonesia). (9pp).

Teklemarian, M., Battaglia, S., Gianelli, G., Ruggieri, G., 1996. Hydrothermal alterations in the Aluto-Langano geothermal field, Ethiopia. Geothermics 25, 679-702.

U.N.D.P.-United Nations Develop. Program, 1973. Investigation of Geothermal Resources of Power Development: Geology, Geochemistry and Hydrogeology of Hot Springs of the East Africa Rift System Within Ethiopia. DP/SF/UN 116 Technical Report, United Nations, New York (275 pp).

Vaselli, O., Tassi, F., Montegrossi, G., Capaccioni, B., Giannini, L., 2006. Sampling and analysis of fumarolic gases. Acta Vulcanol. 1-2, 65-76.

Venturi, S., Vaselli, O., Rossato, L., Tassi, F., Nisi, B., Pennisi, M., Cabassi, J., Bicocchi, G., 2015. Anthropogenic inputs of boron in the groundwater system from an industrial area near Arezzo (Tuscany, Central Italy). Appl. Geochem. 63, 146-157.

Zanettin, B., Justin-Visentin, E., Nicoletti, M., Petrucciani, C., 1978. Evolution of the Chencha escarpment and the Ganjiuli graben (Lake Abaya) in the southern Ethiopian Rift. N. Jb. Geol. Paläont. Mh. 8, 473-490. 